\title{
Mesoscale Disturbance and Ecological Response to Decadal Climatic Variability in the American Southwest
}

\author{
Thomas W. Swetnam \\ Laboratory of Tree-Ring Research, The University of Arizona, Tucson, Arizona \\ JULiO L. BETANCOURT \\ Desert Laboratory, U.S. Geological Survey, Tucson, Arizona
}

(Manuscript received 14 January 1997, in final form 31 July 1997)

\begin{abstract}
Ecological responses to climatic variability in the Southwest include regionally synchronized fires, insect outbreaks, and pulses in tree demography (births and deaths). Multicentury, tree-ring reconstructions of drought, disturbance history, and tree demography reveal climatic effects across scales, from annual to decadal, and from local $\left(<10^{2} \mathrm{~km}^{2}\right)$ to mesoscale $\left(10^{4}-10^{6} \mathrm{~km}^{2}\right)$. Climate-disturbance relations are more variable and complex than previously assumed. During the past three centuries, mesoscale outbreaks of the western spruce budworm (Choristoneura occidentalis) were associated with wet, not dry episodes, contrary to conventional wisdom. Regional fires occur during extreme droughts but, in some ecosystems, antecedent wet conditions play a secondary role by regulating accumulation of fuels. Interdecadal changes in fire-climate associations parallel other evidence for shifts in the frequency or amplitude of the Southern Oscillation (SO) during the past three centuries. High interannual, fire-climate correlations $(r=0.7$ to 0.9$)$ during specific decades (i.e., circa $1740-80$ and $1830-$ 60) reflect periods of high amplitude in the SO and rapid switching from extreme wet to dry years in the Southwest, thereby entraining fire occurrence across the region. Weak correlations from 1780 to 1830 correspond with a decrease in SO frequency or amplitude inferred from independent tree-ring width, ice core, and coral isotope reconstructions.

Episodic dry and wet episodes have altered age structures and species composition of woodland and conifer forests. The scarcity of old, living conifers established before circa 1600 suggests that the extreme drought of 1575-95 had pervasive effects on tree populations. The most extreme drought of the past 400 years occurred in the mid-twentieth century (1942-57). This drought resulted in broadscale plant dieoffs in shrublands, woodlands, and forests and accelerated shrub invasion of grasslands. Drought conditions were broken by the post1976 shift to the negative SO phase and wetter cool seasons in the Southwest. The post-1976 period shows up as an unprecedented surge in tree-ring growth within millennia-length chronologies. This unusual episode may have produced a pulse in tree recruitment and improved rangeland conditions (e.g., higher grass production), though additional study is needed to disentangle the interacting roles of land use and climate. The 1950s drought and the post-1976 wet period and their aftermaths offer natural experiments to study long-term ecosystem response to interdecadal climate variability.
\end{abstract}

\section{Introduction}

Climatic variables such as radiation, temperature, and precipitation determine rates of ecosystem processes from net primary productivity to soil development. They predict a wide array of biogeographic phenomena, including soil carbon pools, vegetation physiognomy, species range, and plant and animal diversity. Climate also influences ecosystems indirectly by modulating the frequency, magnitude, and spatial scales of natural distur-

Corresponding author address: Dr. Thomas W. Swetnam, Laboratory of Tree-Ring Research, The University of Arizona, Building \#58, Tucson, AZ 85721.

E-mail: tswetnam@1trr.arizona.edu bances (Clark 1988; Overpeck et al. 1990; Swetnam 1993)

Disturbance is any discrete event that results in the sudden mortality of biomass on a timescale significantly shorter than that of its accumulation (Huston 1994). A broader definition would include any abrupt event that disrupts community structure and changes the physical environment, resources, or availability of space (White and Pickett 1985). Much of the focus in disturbance ecology has been on the patch dynamics produced by resetting of succession within portions of an ecosystem (so-called gap disturbances). Emphasis has shifted from how disturbances produce landscape mosaics to how these mosaics in turn predispose the landscape to further disturbance. Both spatial and temporal scale enter the 
discussion about whether disturbance helps to maintain or prevent ecosystems from ever reaching equilibrium.

The current paradigm favors a nonequilibrium perspective, but steady states may be scale dependent. Theoretically, if areas affected by disturbance are sufficiently small, then a self-reproducing steady state can exist as an average condition over relatively larger areas (Sousa 1984; Rogers 1996; Turner et al. 1993). A regional steady state is unlikely wherever mesoscale disturbances $\left(10^{4}-10^{6} \mathrm{~km}^{2}\right)$ recur on timescales shorter than the successional cycles necessary to reach and maintain equilibrium across a region (Romme 1982; Barden 1988; Sprugel 1991; Swetnam 1993; Turner et al. 1993). One such place is the American southwest, where rates of plant and population growth are sluggish; soil properties accumulate only gradually $\left(10^{3}-10^{5} \mathrm{yr}\right)$ and are usually in disequilibrium with current climate and vegetation; meager soil water and organic matter cannot buffer climatic extremes; and episodic mortality from drought, insect outbreaks, and fire is often synchronized and broadscale.

In this paper, we explore the effects of climatic variability and mesoscale disturbance on nonriparian ecosystems of the American southwest. We emphasize decadal and regional scales for three reasons. First, the mean generation times of most of the woody perennials that dominate from the lowland deserts to upland forests are from 15 to $50 \mathrm{yr}$; hence these are the minimal time spans to observe their population dynamics. Second, there is ample evidence for climate behavior on decadal scales (15-30-yr period) in both the instrumental (Cayan et al. 1998; Dettinger et al. 1998; Cayan and Webb, 1992; Webb and Betancourt 1992) and tree-ring records of the American Southwest (Fritts 1991; Cleaveland et al. 1992; Dettinger et al. 1998; Grissino-Mayer 1996). Last, local and shorter time frames have dominated empirical and experimental work in ecology, as well as resource management, while regional and historical perspectives have been neglected (Ricklefs 1987; Brown 1995). Experimentation is valuable for clarifying mechanisms, but is generally impractical or impossible at regional or decadal to centennial timescales. In the Southwest, long-term perspectives on ecosystem response to climate and disturbance are abetted by a long tradition of vegetation monitoring (Goldberg and Turner 1984; Turner 1990; McCormick and Galt 1993; Martin 1986; Avery et al. 1976; Brown and Heske 1990; Pake and Venable 1995), and the ability to cross-date and map past climatic variations, disturbances, and tree demography at interannual resolution using tree rings (Fritts and Swetnam 1989).

Our goals in this paper are to 1) explore the complexity of climate-disturbance relationships, 2) demonstrate the synchroneity and spatial extent of fires and drought-related plant mortality (and establishment), and 3 ) use extreme episodes such as the 1950s drought and the post-1976 climatic shift to illustrate the impacts of decadal-scale climate on ecosystems and the present challenge of disentangling natural and cultural factors.

\section{Disturbance climates of the American southwest}

\section{a. Seasonal variability}

In the American southwest, seasonal precipitation is characterized by a highly variable winter-early spring (November-March), an arid late spring and foresummer (April-June), monsoonal rains in July and August, and a dry autumn (September-October; Fig. 1). In general, cool season precipitation recharges soil moisture and controls woody plant growth, whereas summer rains drive the annual grass production that supports the livestock industry. Synergism between seasonal precipitation and lightning activity yields a vigorous fire regime in late spring-early summer. During the arid foresummer (Fig. 1) fuels are dry, convective storms begin to generate lightning, and the maximum area is burned in June. Subsequently, full development of the monsoonal pattern in July leads to a maximum in numbers of lightning-ignited fires, but increasing fuel moisture results in reduced area burned (Fig. 2).

Although the influence of seasonal climatic variability on wildland fires is intuitively obvious-droughts are correlated with fire- the predictive aspects of this association are poorly understood. Recently, there has been a surge of interest and research in fire climatology, driven in part by recognition of ENSO teleconnections and concern over potential impacts of future climatic change on wildfire activity (Simard et al. 1985; Swetnam and Betancourt 1990; Brenner 1991; Balling et al. 1992; Flannigan and van Wagner 1991; Johnson and Wowchuk 1993; Larsen and McDonald 1995; Knapp 1995; Price and Rind 1994). In contrast to traditional emphasis on short-term and local weather (temperature, relative humidity, and wind speed) effects on fire (Rothermel 1983), more recent studies focus on relatively large spatial and long temporal scales, that is, regional to continental and seasonal to decadal.

In the Southwest, plant communities experience episodic recruitment and mortality of seedlings and adults (Betancourt et al. 1993). To survive its first year, a new seedling must endure frost and seasonal drought. If winter is dry, there may be insufficient soil moisture for fast growth in the spring-early summer. If summer rains fail, the arid foresummer extends into the hottest time of the year, and even the hardiest of seedlings will wither and die. One outcome of seasonal or longer droughts is a lull in plant recruitment. Conversely, wet and/or warm conditions favor above-average seed germination and survival of seedlings leading to recruitment pulses. These pulses may be dominated by single-year events, such as the year 1919 in many Southwestern ponderosa pine stands (Pearson 1950; Savage et al. 1996), or they may be clustered in favorable decades (White 1985). 

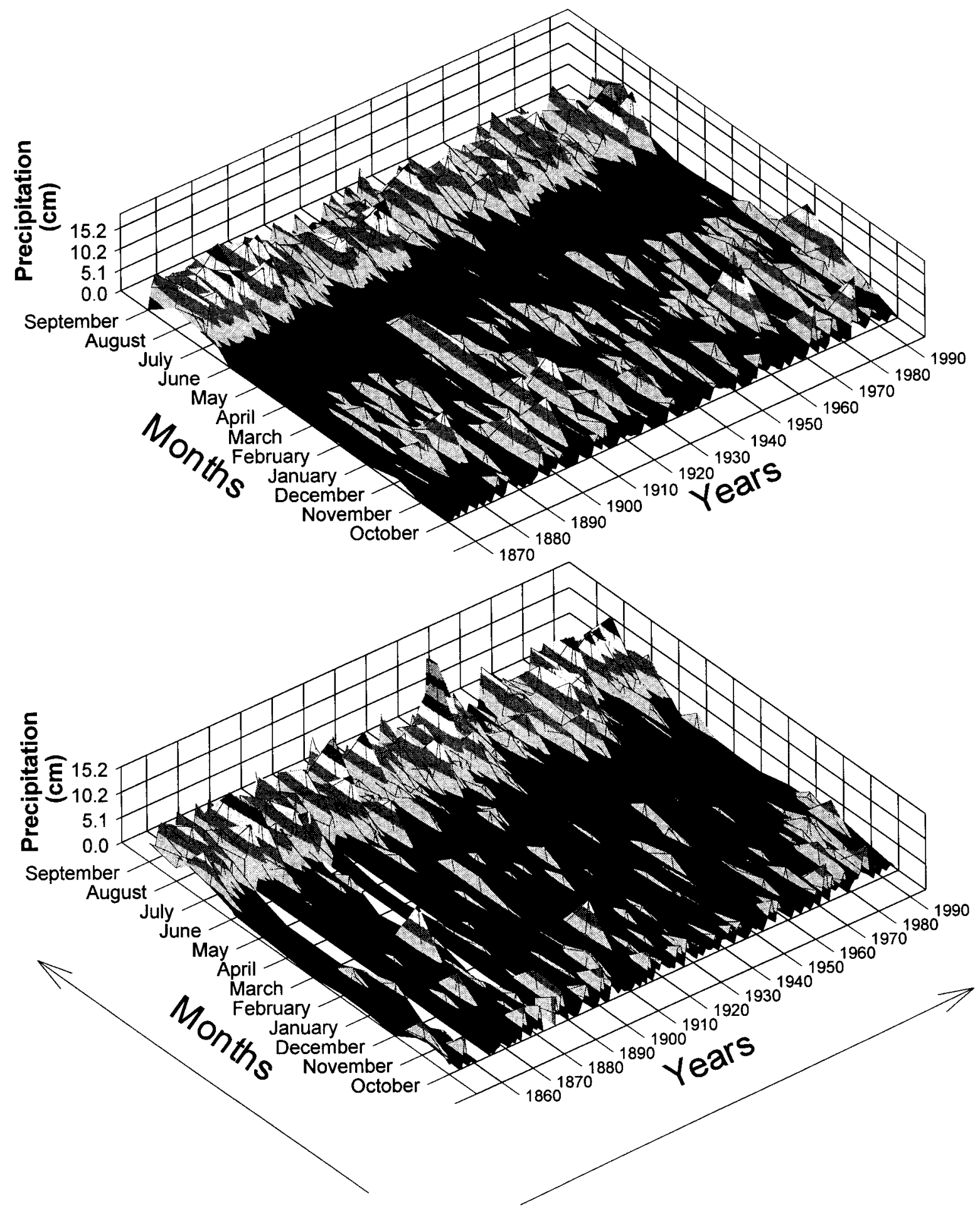

FIG. 1. Three-dimensional time series plots of monthly precipitation totals from Tucson, Arizona, 1870-1995 (upper plot), and Las Cruces, New Mexico, 1853-1995 (lower plot). Areas shaded black are months with less than approximately $2.5 \mathrm{~cm}$ of precipitation. Note the persistence of winter and summer drought in Las Cruces during the 1950s and the post-1976 increase in cool season precipitation in both Tucson and Las Cruces. 


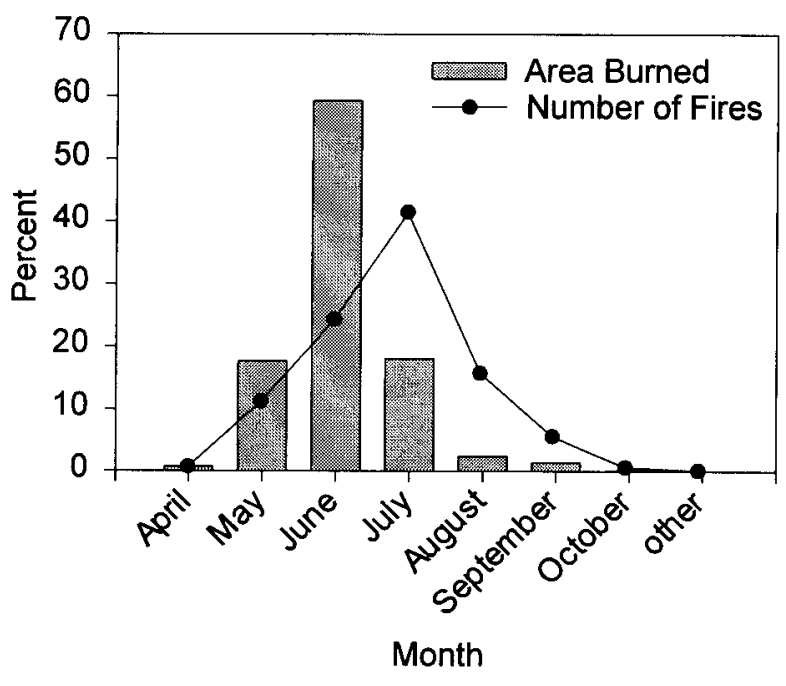

FIG. 2. Monthly distribution of numbers and area burned by lightning fires in Arizona and New Mexico national forests, 1940-74 (Barrows 1978)

\section{b. Interannual and interdecadal climate variability}

Interannual variability in southwestern precipitation is linked to shifts in the upper-air westerlies and ENSO. During the warm SO phase, warm waters in the eastern Pacific provide the necessary energy for development of troughs along the west coast of North America; the warm waters also weaken the trade wind inversion, resulting in stronger subtropical westerlies. Although there appears to be no single canonical response in the polar jet stream, the midlatitude winter storm track is usually displaced southward during El Niño episodes. In general, an expanded circumpolar vortex, with strengthened westerly winds centered about $30^{\circ} \mathrm{N}$ and positive 700-mb height anomalies at higher latitudes, prevails during decades when the Southern Oscillation approaches a biennial cycle (Cayan and Webb 1992; Webb and Betancourt 1992; Cayan et al. 1998). In the Southwest, El Niño (La Niña) conditions are associated with wetter (drier) winters and springs (Andrade and Sellers 1988) and drier (wetter) summers in year +1 after the onset of El Niño (Harrington et al. 1992).

Teleconnections between the tropical Pacific and American southwest have been shown by correlations between indices such as Southern Oscillation index, equatorial sea surface temperatures, and Line Island rainfall against southwestern precipitation (Douglas and Englehart 1984; Andrade and Sellers 1989; Cayan and Webb 1992), streamflow (Cayan and Webb 1992; Webb and Betancourt 1992; Kahya and Dracup 1994), and annual area burned in Arizona and New Mexico (Swetnam and Betancourt 1990; Price and Rind 1994). These teleconnections tend to be lagged, promising some predictive capability a season or more in advance. Although linear regressions provide weak predictive capability (about $25 \%-30 \%$ of the variance) for precipitation, streamflow, and fire, the mesoscale responses to extreme phases of the SO are highly consistent. This predictability, for example, allows managers to schedule control fires or to improve fire readiness depending on the onset of El Niño or La Niña conditions, respectively (Swetnam and Betancourt 1990). For example, based on La Niña conditions in fall 1995 and National Oceanic and Atmospheric Administration (NOAA) forecasts (Climate Prediction Center) for a dry Southwestern winter and spring, emergency funds were obtained and used to combat a heavy 1996 fire season (Albuquerque Journal, 14 April 1996, and The New York Times, 11 May 1996).

Evidence for climate behavior on interdecadal scales (15-30-yr period) has been demonstrated empirically from historical climate datasets (Namias et al. 1988; Rasmusson et al. 1990; Halpert and Ropelewski 1992; $\mathrm{Xu}$ 1993; Ghil and Vautard 1994; Latif and Barnett 1994; Trenberth and Hurrell 1994; Miller et al. 1994; Mann et al. 1995; Cayan et al. 1998; Dettinger et al. 1998) and high-resolution (annual) climate proxies including tree rings, corals, marine and lake sediment varves, and ice cores (Ebbesmeyer et al. 1991; Diaz and Pulwarty 1994; Dunbar et al. 1994; Meko et al. 1993; Meko et al. 1995; Slowey and Crowley 1994; Stocker and Mysak 1992; Fritts 1991; Cleaveland et al. 1992; Stahle and Cleaveland 1993). In the American southwest, three different tree-ring reconstructions of the Southern Oscillation suggest that the frequency and amplitude of the SO, and/or the strength of its teleconnections with winter precipitation in this region, has varied on decadal to multidecadal timescales (Lough and Fritts 1985; Michaelsen and Thompson 1992; Stahle and Cleaveland 1993). During the twentieth century, decadal trends are evident in time series of monthly mean sea level pressure in the North Pacific and SOI (Trenberth and Hurrell 1994). In the Southwest, twentieth century climatic trends stemming from the interdecadal behavior of the westerlies and the tropical $\mathrm{Pa}-$ cific include wet winters in the early part of the century (1905-30), a midcentury dry period (1942-64), and warm, wet winters and erratic summers since 1976 (Fig. 1).

In sections to follow, we illustrate and discuss a range of ecological responses to interannual and interdecadal climatic variability in the American southwest.

\section{Regionally synchronized insect outbreaks}

Outbreaks of phytophagous insects are one of the most dramatic and poorly understood mesoscale ecological phenomena (Barbosa and Schultz 1987). The cyclical or aperiodic eruption of insect populationssometimes from rare, endemic levels, to broadscale outbreaks covering $10^{4}-10^{5} \mathrm{~km}^{2}$ - has been known at least since biblical times (e.g., locust plagues), and associated anecdotally with drought. The drought connection was formalized by White (1976) in the "stress" hypothesis, 
which stated that moisture and heat-stressed plants have a higher food quality than nonstressed plants. Highly variable and sometimes contradictory results of both observational and experimental studies, however, have fostered continued debate about insect, plant, and drought interactions (Larsson 1989; Martinat 1987; Price 1991; Mopper and Whitham 1992). Part of the difficulty in identifying the role of climatic fluctuations in outbreak dynamics has been the lack of sufficiently long and large-scale records of climate or insect populations. This is particularly true for major forest defoliators, such as the western spruce budworm (Choristoneura occidentalis) and the eastern North American species (Choristoneura fumiferana), which have repeatedly erupted over regional areas at frequencies of only four or fewer outbreaks in the twentieth century (Sanders et al. 1985).

Tree-ring reconstructions of multicentury length budworm outbreak histories are possible because past defoliation of host trees by the budworm larvae cause distinctive growth reductions in tree-ring width series of surviving trees (Blais 1962). When nonhost tree species (pines) are sampled in nearby sites and their ring series examined in comparison with the host tree species (firs and spruces), effects of climatic variation can be distinguished from the host-specific defoliation effects (Swetnam and Lynch 1993). These approaches have yielded 300-yr reconstructions of budworm outbreaks in the central and southern Rockies of Colorado and New Mexico (Swetnam and Lynch 1993; Hadley and Veblen 1993; Weber and Schweingruber 1995) and the Blue Mountains of eastern Oregon (Swetnam et al. 1995). Independently derived tree-ring reconstructions of June Palmer drought severity index (PDSI) from nonhost tree species show that, over the past three centuries, budworm outbreaks generally coincided with wet periods, whereas low budworm population levels corresponded to droughts (Fig. 3). These tree-ring reconstructed patterns are supported by similar comparisons between twentieth century time series of defoliated area (from aerial and ground measurements) and meteorological data in the twentieth century (Swetnam and Lynch 1993).

The positive association between precipitation or drought indices and budworm population proxies over such a long period and large spatial scale supports a "vigor" rather than a stress hypothesis (Price 1991). This finding is supported by experimental results showing that, in the case of some leaf or bud feeding insects, food quality and quantity may be enhanced by increased moisture (Larsson 1989). In contrast, drought inhibits the resin production that defends a tree against cambium feeders (e.g., bark beetles) (Craighead 1925; Lorio 1986). For example, bark beetle outbreaks were associated with broadscale tree mortality during the 198692 drought in the Sierra Nevada (Ferrell 1996).

Increasing drought stress and susceptibility due to increasing leaf area is touted as the leading cause of declining "forest health" in the Mountain West (e.g., Langston 1995; Rogers 1996), but clearly, there can be a variety of responses by mesoscale disturbance agents to both wet and dry periods. Another layer of complexity is added when we consider that insect outbreaks also influence subsequent fire activity by increasing highly flammable dead leaves and woody fuels (Schowalter et al. 1986; Stocks 1987). Although these synergisms are widely noted, their temporal and spatial dynamics are virtually unexplored and unknown.

\section{Regionally synchronized wildfires}

In most terrestrial ecosystems, fire is a keystone process that is heavily influenced by climatic variability. Seasonal to interdecadal variability in precipitation, temperature, wind, and lightning regimes determine fuel dynamics and ignition rates. The role of climate is most evident in the recurrence of regionally synchronized wildfires during particular years. No other factor can explain the prevalence and synchroneity of such unusual fire activity.

The American southwest has the longest and most detailed records of drought and fire history in the world. Multicentury networks of ring-width and fire-scar data allow assessment of fire-climate relations at seasonal to century scales, as well as estimation of the magnitude, extent and frequency of regional, synchronous fires. For our analyses we used 13 gridpoint reconstructions of June PDSIs extending back to 1700 . These reconstructions were derived from more than 100 ring-width chronologies (Meko et al. 1993; Cook et al. 1996) from throughout the region. Sixty-three fire-scar chronologies, specifying dates of fires during the last $400 \mathrm{yr}$, have been compiled from ponderosa pine, mixed-conifer, and pine-oak woodlands in 25 mountain ranges (Fig. 4) (Swetnam and Baisan 1996). Dates were determined by obtaining cross sections from 10 or more fire-scarred trees in each stand of 10-100 ha, crossdating ring-width patterns, and determining the year of firescarring (formation of heat-caused lesions with the xylem tissue). Fire-scar dates from more than 900 trees are included in this dataset.

The composite fire-scar record across the Southwest shows that regionally synchronous fires have recurred for centuries (Fig. 5). Fire frequency within individual sites averaged about one fire per $7.5 \mathrm{yr}$ from 1700 to 1900. At this frequency, strictly by chance, we would expect about one coincidence of the same fire date in 21 of the 63 sites (one-third) in about a 35000 -yr period. Yet, 15 different years met or exceeded this criterion in the 201-yr period (Fig. 5). The probability of 41 of 63 sites recording the same fire date by chance, as in 1748, is astronomically low (one chance in billions)! As in 1910 (Fig. 6), this synchroneity of fires across such a large region must reflect regional to subcontinentalscale drought for one or more seasons. Direct comparison of the fire-scar records with independent PDSI re- 


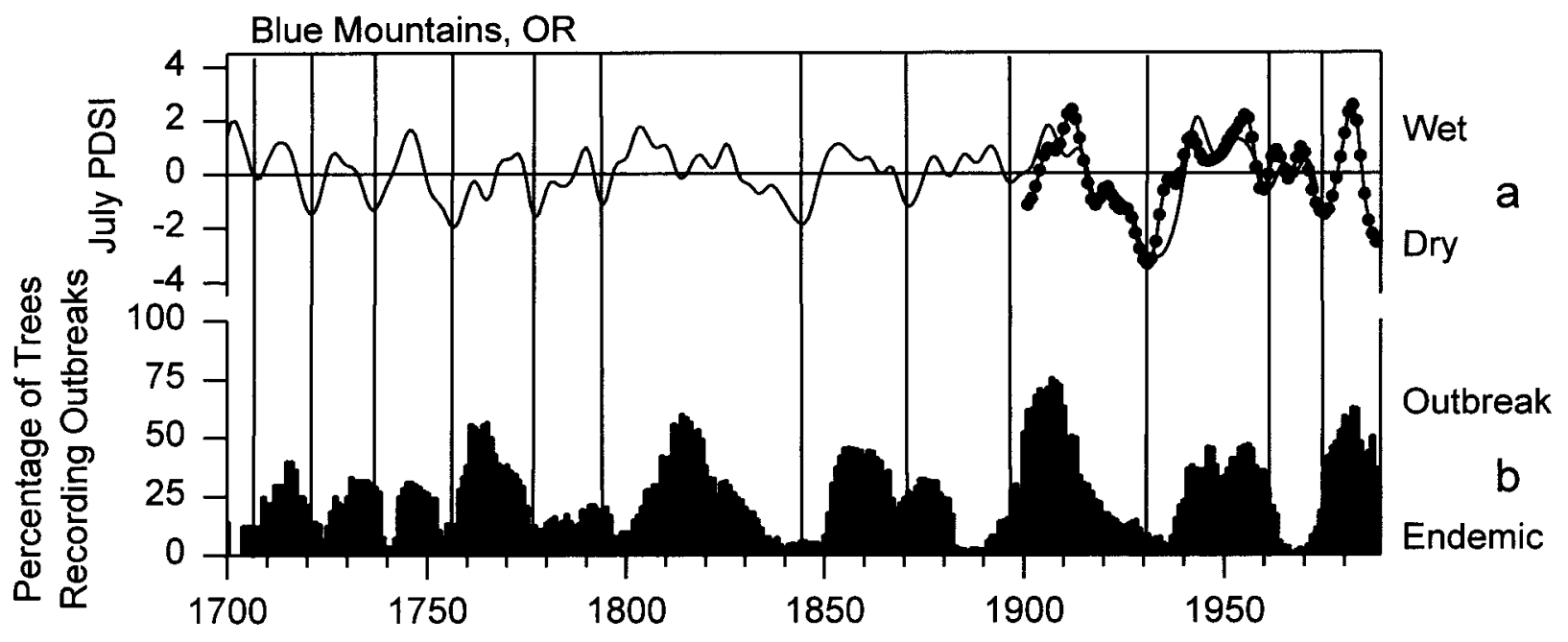

Southern Rockies, NM

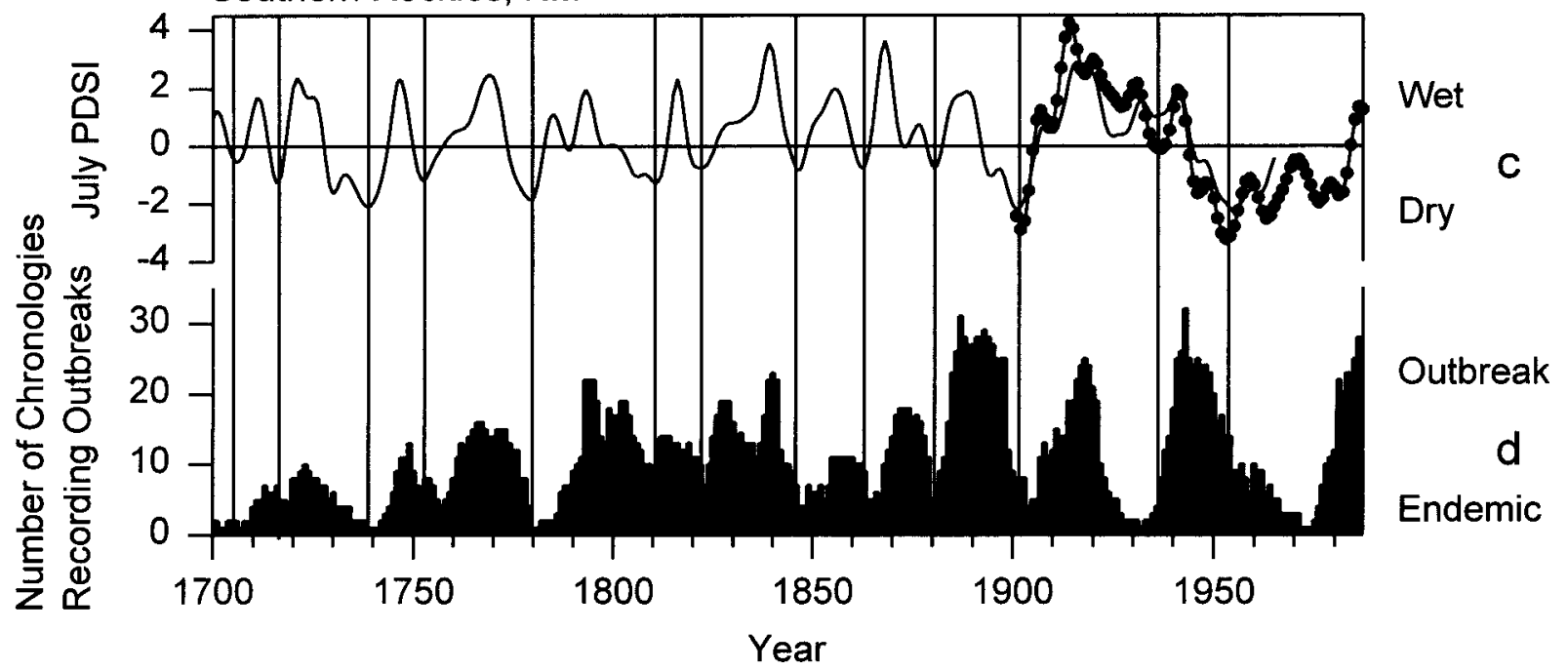

FIG. 3. Tree-ring reconstructed histories of western spruce budworm outbreaks in (b) Oregon and the (d) southern Rockies compared to (a), (c) tree-ring reconstructed July PDSI from the same regions (Cook et al. 1996). The lines with solid circles during the twentieth century in (a) and (c) are PDSI values estimated from weather station records (Cook et al. 1996). The PDSI series are smoothed with a 13-weight low-pass, Gaussian filter. The vertical lines show approximate correspondence between drought periods and periods of endemic (low) budworm activity; the lines are centered on the lowest years of the smoothed PDSI.

constructions confirms the importance of extreme drought in synchronizing fire activity across the region (Fig. 7).

The drought-fire association also involves lags with antecedent moisture conditions. We used "superposed epoch analysis" (SEA; Lough and Fritts 1987; Swetnam 1993 ) to compute the mean PDSI values during the 20 largest and 20 smallest fire years from 1700 to 1900 (derived from the composite fire-scar record; Fig. 5), and the 10 largest and 10 smallest events from 1920 to 1978 (derived from regional fire statistics; Swetnam and Betancourt 1990; Swetnam and Baisan 1996). The mean PDSI values also were computed for each of the $5 \mathrm{yr}$ before (years $-1--5$ ) and 2 yr after (year 1 and 2) each event. A Monte Carlo simulation was used to es- timate confidence intervals around the observed mean values (Mooney and Duvall 1993).

The SEA results show that extreme June drought in year 0 is the primary factor in determining the severity of the fire year (i.e., a high percentage of sites with fire scars between 1700 and 1900, or large areas burned from 1920 to 1978) (Fig. 8a). Conversely, wet conditions (positive PDSI values) correspond with low fire activity. Lags are only significant in open ponderosa pine forests, where antecedent wet conditions affect fine fuel (e.g., grass) production in years $-1--3$ prior to large fire years (Fig. 8b). This phenomenon may involve both the increased production of fine fuels during wet years prior to large fire events, and fewer fuels during dry years before small fire events (Fig. 8a). One-year 


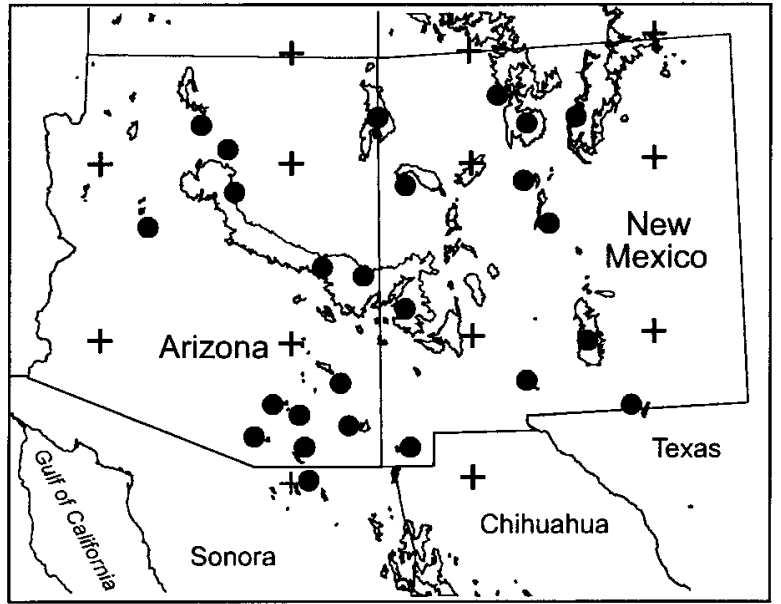

FIG. 4. The southwestern United States showing fire-scar collections (filled circles, indicating approximate location of one or more fire-scar chronologies) and PDSI reconstruction grid points (crosses; Cook et al. 1996). The range of ponderosa pine forest type is shown by irregular outlines.

lags may reflect grass production in open, ponderosa pine parklands; 2-3-yr lags could indicate buildup of needle litter. Ponderosa pine needles are typically retained for 3-5 yr before they are abscised and fall to the forest floor. In mixed-conifer forests, the lack of significant lags (Fig. 8b) could be explained by the deeper soils, greater persistence of snowpack into the spring, and unimportance of fine fuels in fire dynamics. Lags were also insignificant in fire statistics between 1920 and 1978 (Fig. 8a). This could reflect the many vegetation types and varying fire ecologies included in na- tional forests, or changing fire regimes in the twentieth century due to fire suppression, grazing, logging, and other human activities.

Changes in the strength of interannual wet-dry cycles and drought-fire relations are evident in the high-frequency components of the reconstructed records (Fig. 9). The greatest amplitude of interannual switching from wet to dry occurred from 1747 to 1748 , possibly indicating an extreme El Niño followed by a severe La Niña. The largest single regional fire year happened in 1748, with two-thirds of all sampled sites (41) recording a fire during that year. Quinn and Neal's (1992) compilation from archival documents lists 1747 as a strong El Niño year. Coral records from the Galapagos Islands show a conspicuous discontinuity at about this time (1749), suggesting dieback in warm waters (Dunbar et al. 1994). This dieback may have resulted in the loss of the 1747 and/or 1748 coral bands.

Secular variations are evident in correlations between the regional fire-scar and ring-width records. High correlations $(r=0.7-0.9)$ are obtained during the highamplitude periods of 1740-80 and 1830-60. Low fireclimate correlations occur in the period between 1780 and 1830, coincident with a decrease in amplitude of 2-4-yr bandwidth oscillations in the regional fire-scar record (Figs. 10,11). This parallels similar changes in dominant oscillatory modes in Pacific coral records (Dunbar et al. 1994), tree rings, and ice cores (Cleaveland et al. 1992; Michaelsen and Thompson 1992) and suggests that ENSO-fire teleconnections occur at both interannual and interdecadal scales. Variances of both SO and fire activity were high during $1740-80$ and 1830-60 but low from 1780 to 1830 . The early 1800 s

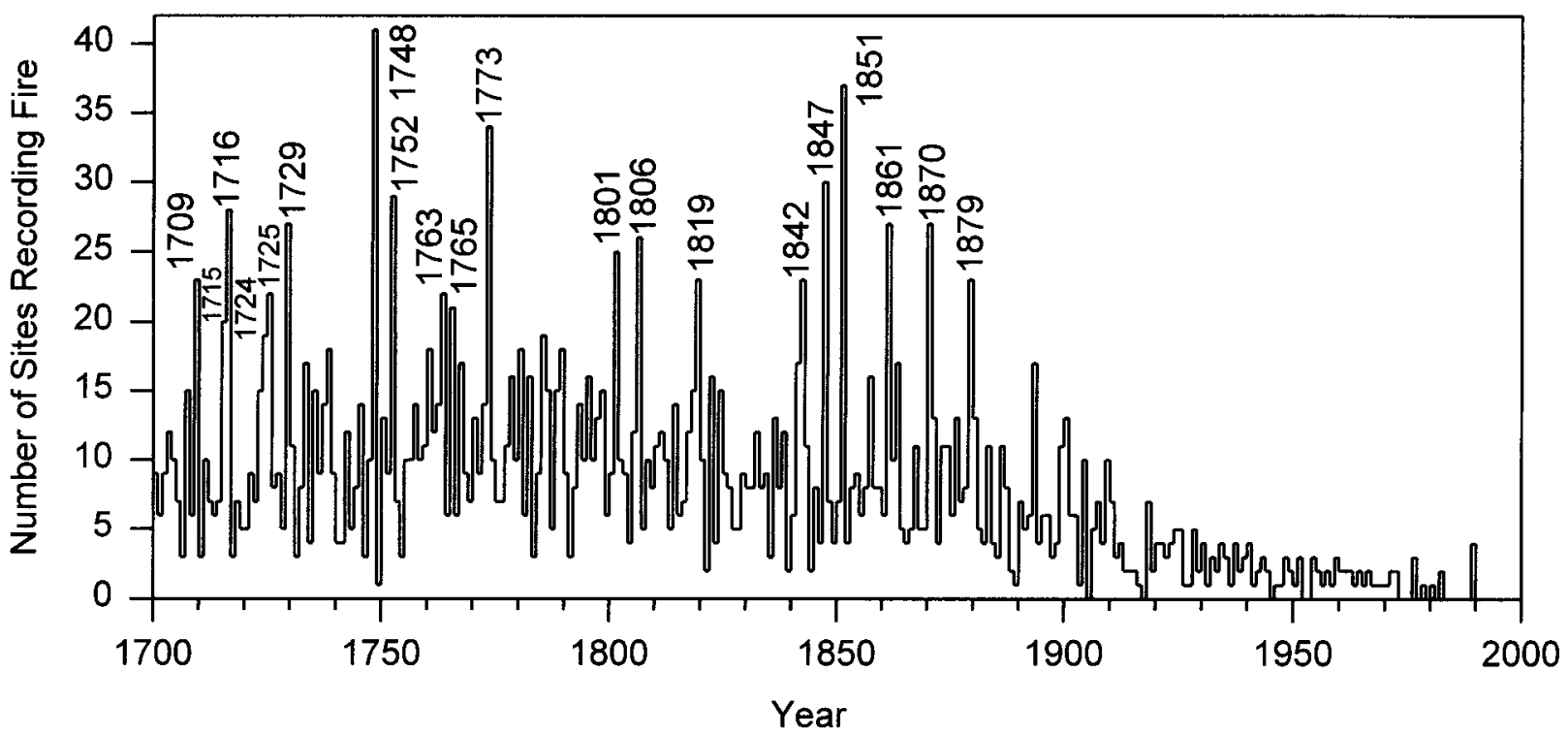

FIG. 5. Number of fire-scar sites (chronologies) in the Southwest recording fire dates in each year, 1700 to present, out of a total of 63 sites. Note the regionally synchronous fire years (labeled), and the decrease in recorded fires after ca. 1900, reflecting livestock grazing affecting fine fuels, and subsequent fire suppression by government agencies. Also note that 1910, the largest twentieth century fire year (see Fig. 6), was unexceptional, suggesting that the eighteenth and nineteenth century regional fire years burned enormous areas by comparison. 


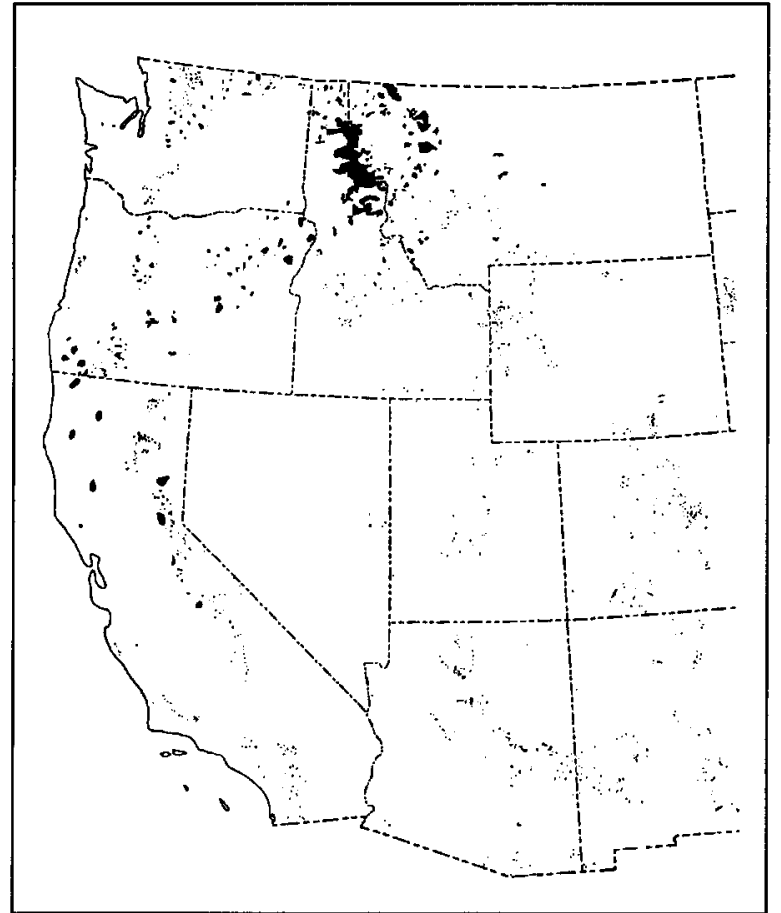

FIG. 6. Areas burned during 1910, the largest fire year of the twentieth century, on national forest lands in the western United States. (Plummer 1912). Enormous fires occurred in all western states, with more than $2 \times 10^{6}$ ha burned on national forest lands. The total area burned was actually much larger, since these statistics do not include areas burned on other federal, state, and private lands. At the scale of this map the burned areas in Arizona and New Mexico appear as small specks, yet these areas totaled more than 145000 ha. were notable for cool summers at high, northern latitudes (D'Arrigo and Jacoby 1992; Jacoby and D'Arrigo 1993; Luckman 1996; Shiyatov et al. 1996), and wet winters-springs in the Southwest (Meko et al. 1993; Fritts 1991). More than half of the fire-scar chronologies show lower fire frequencies during the 1780-1830 period. Although apparently less variable, the exact nature of 1780-1830 climate in the tropical Pacific or in the American Southwest is uncertain. If this was a time of average SSTs in the tropical Pacific, then wet winters in the American southwest, normally attributed to ENSO, could be explained by persistence of a positive Pacific-North American pattern (a more sinuous and southerly displaced polar jet stream) decoupled from ENSO.

Secular variations in fire-climate relations may be confounded by anthropogenic effects. Extreme fire years in the early twentieth century (e.g., 1910; Fig. 6) catalyzed an aggressive national program in fire suppression (Pyne 1982), which has resulted in accumulated fuels and pervasive changes in forest structure and composition. Synergism between long-term fire suppression (accumulated fuels) and a shift in climate could explain recent increases in annual area burned in Canada (van Wagner 1988; Auclair and Carter 1993) to the southwestern United States (Sackett et al. 1994) (Fig. 12). In the American southwest, for example, annual area burned is on the rise despite relatively wet winters since 1976. This rise could be due to more frequent, dry summers, to increased frequency of human ignitions, and/ or to greater accumulation of both fine and coarse fuels, with wetter winters and long-term fire suppression, re-

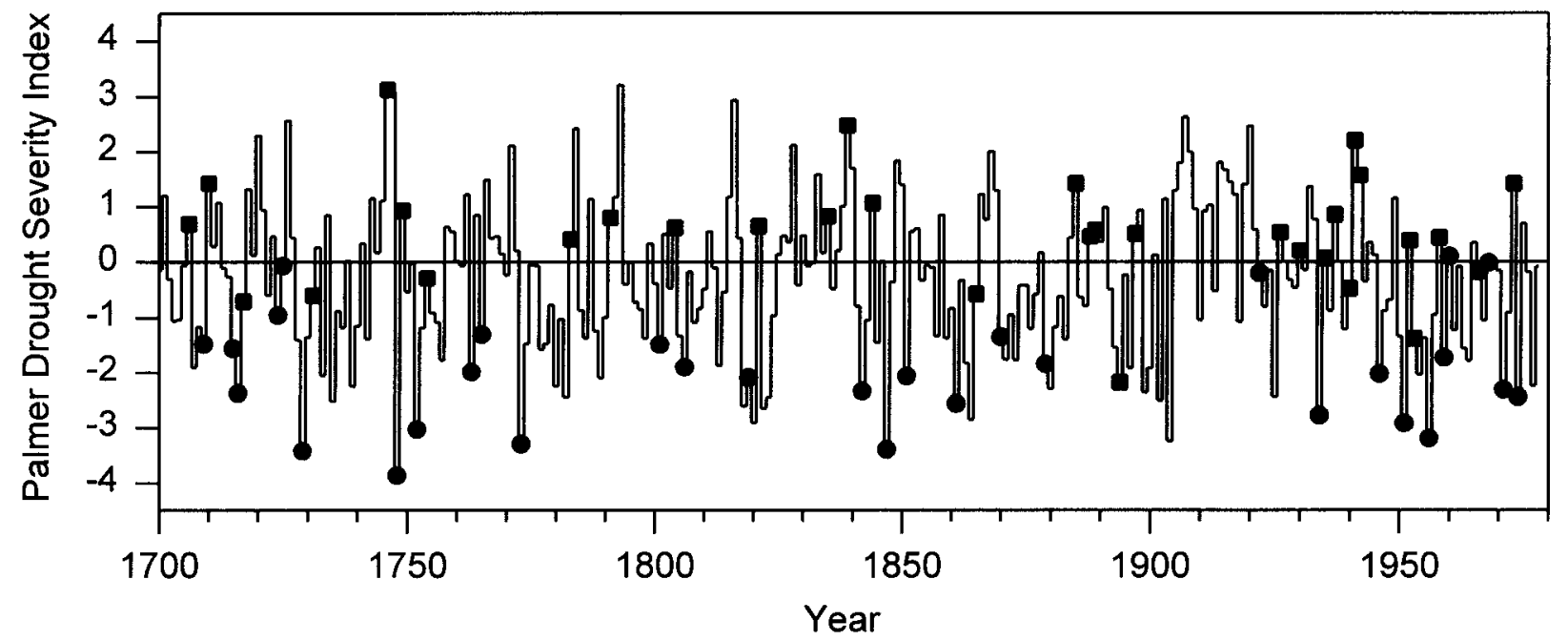
- Pre-1900: < 4 Sites Recording Fires Post-1920: < 1,300 Ha Burned

\section{- Pre-1900: > 18 Sites Recording Fires Post-1920: > 10,000 Ha Burned}

FIG. 7. Tree-ring reconstructed June-August Palmer drought severity indices, averaged from the 13 gridpoint reconstructions shown in Fig. 4. The circles and squares show the largest and smallest fire years in the regional fire-scar network (1700 to 1900, $20 \mathrm{yr}$ each) and the largest and smallest fire years in the area burned per year record from all national forests lands in Arizona and New Mexico (1920-78, 10 yr each). 


\section{a Large Fire Years Small Fire Years}
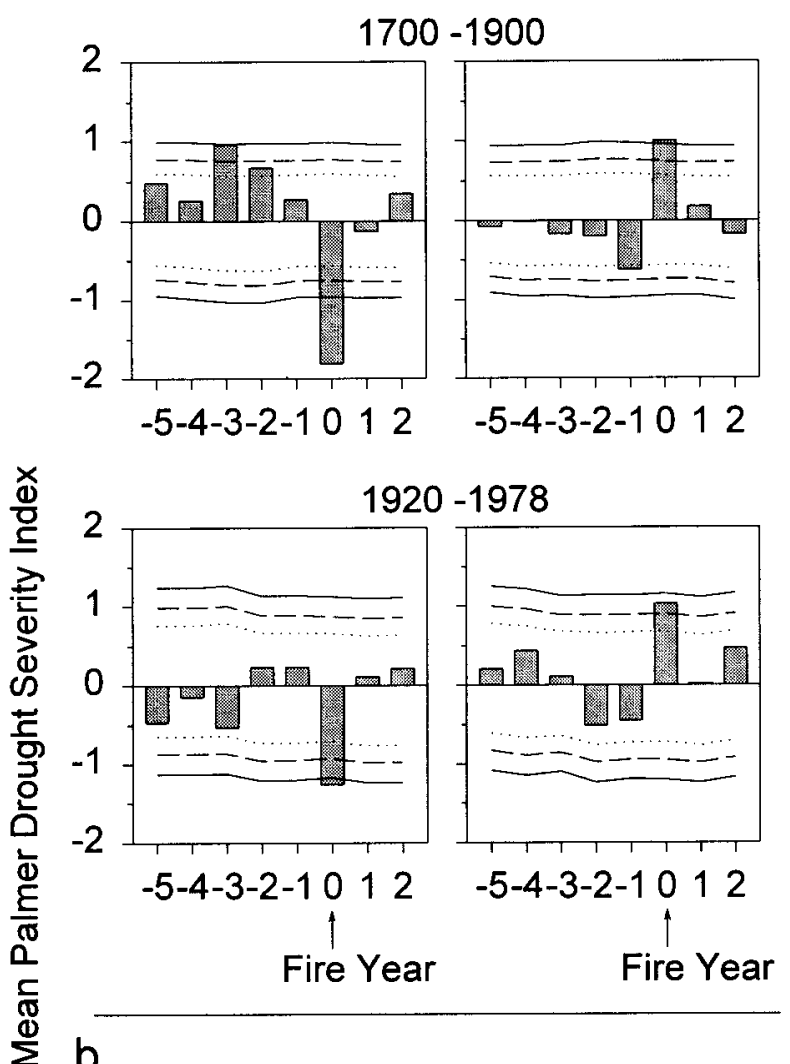

$b$

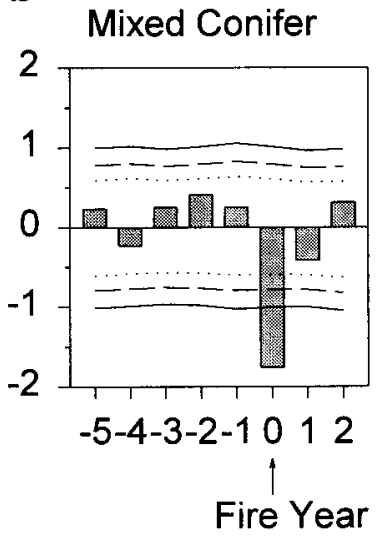

Ponderosa Pine

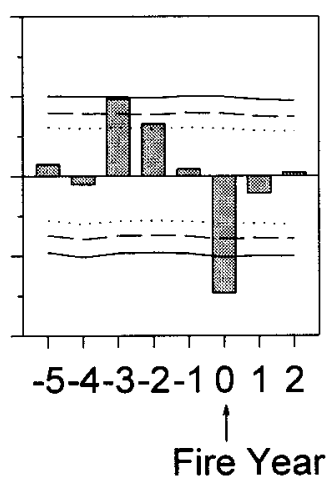

FIG. 8. Results of superposed epoch analysis showing mean JuneAugust Palmer drought severity indices during the largest and smallest fire years (year 0), and during lagged years preceding the fire years (lag years $-5--1$ ), and following the fire years (lag years 1 and 2). The horizontal solid, dashed, and dotted lines are the 95, 99, and 99.9 percent confidence intervals, respectively, computed by Monte Carlo simulation. (a) The upper two sets of plots show the climate-fire patterns for all fire-scar sites (1700-1900) and national forest area burned statistics (1920-78). The large and small fire years used in this analyses are the years with filled circles and squares, respectively, in Fig. 7. (b) The lower set of plots show the climatefire patterns for large fire years in mixed-conifer sites compared to ponderosa pine sites (1700-1900). spectively. Greater annual area burned elsewhere in the West may be equally complex, attributed to prolonged drought, accumulated fuels with fire suppression, and higher fire frequency and extent with historic cheatgrass (Bromus tectorum) invasion into the expansive shrublands of the intermountain West.

The annual cost of suppressing these increased wildfires is now approaching one billion dollars, not including losses in timber and property, as well as soil erosion and other watershed effects. The cost is significantly higher during extreme years, hence the need to understand regionally synchronous fires with a historical perspective on climate variability and the antecedent effects of land use on forest composition and structure. A research challenge is to determine the extent to which increasing insect outbreaks and area burned since the mid-1970s reflect long-term land use and policy effects on forests versus decadal-scale climatic trends (Auclair and Bedford 1994).

\section{Demographic consequences of catastrophic drought: The 1950s dieback}

Tree mortality and autopsy traditionally have been the domain of plant pathologists and entomologists. Not surprisingly, the prevailing view is of drought as an indirect, or secondary factor that predisposes plants to disease or insect outbreaks (Mattson and Haack 1987; Waring 1987). For various reasons, disturbance ecologists have resisted the idea of physiological stress causing tree death directly. When European and North American forests began to decline during the 1980s, air pollutants were implicated, from acid rain to ozone (Hinrichsen 1987). As research progressed through the late 1980s, it became evident that climatic factors (e.g., winter freezes or desiccation) were at least partly involved in tree decline and death (Auclair 1993; Innes 1993). In general, disturbance ecologists have ignored the direct impact of catastrophic drought on mesoscale diebacks, with some notable exceptions (Jane and Green 1983; Barden 1988; Betancourt et al. 1993; Elliott and Swank 1994; Savage 1994; Villalba and Veblen 1997). Although not well understood, tree death may occur with extensive rootlet mortality, diminished water transport, and prolonged xylem cavitation during droughts.

A possible scenario for physiological dieback is as follows. In the summer after a severe winter-spring drought, reduced evaporation (soil moisture) increases the sensible heat flux, which in practice means warmer surface temperatures locally. The incident solar radiation that is normally spent toward evaporating soil moisture heats up the soil instead, and the elevated soil temperatures cause rootlet mortality across the stand (e.g., Redmond 1955). Trees with severely damaged roots translocate water poorly (Greenidge 1953) and sapwater tends to collect in the lower boles, creating a sumplike condition (Auclair 1993). As the dry, hot summer progresses, tracheids and/or vessels in the xylem become 


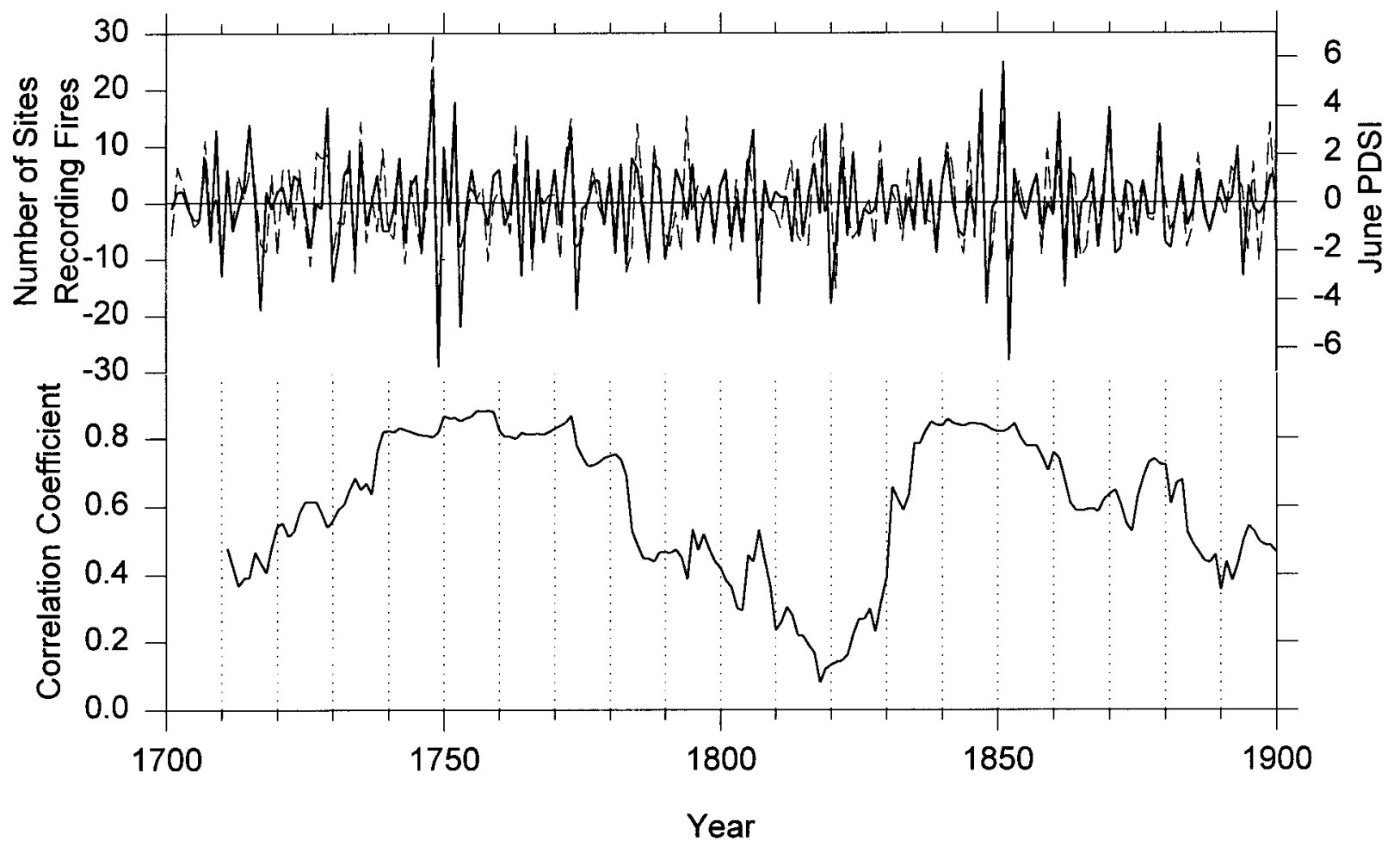

FIG. 9. Correlation of tree-ring reconstructed regional fire-scar chronology and June-August PDSI time series from the Southwest. The upper plot shows the first differences [year $(t)-$ year $(t-1)]$, which emphasize the year-to-year, high-frequency changes in the two time series. Note that the PDSI series was multiplied by minus 1 so that positive changes in PDSI (drying condition) correspond with positive changes in fire activity (increased numbers of sites recording fire scars). The lower plot shows the 21-yr moving correlation coefficients for the two time series plotted on central years.

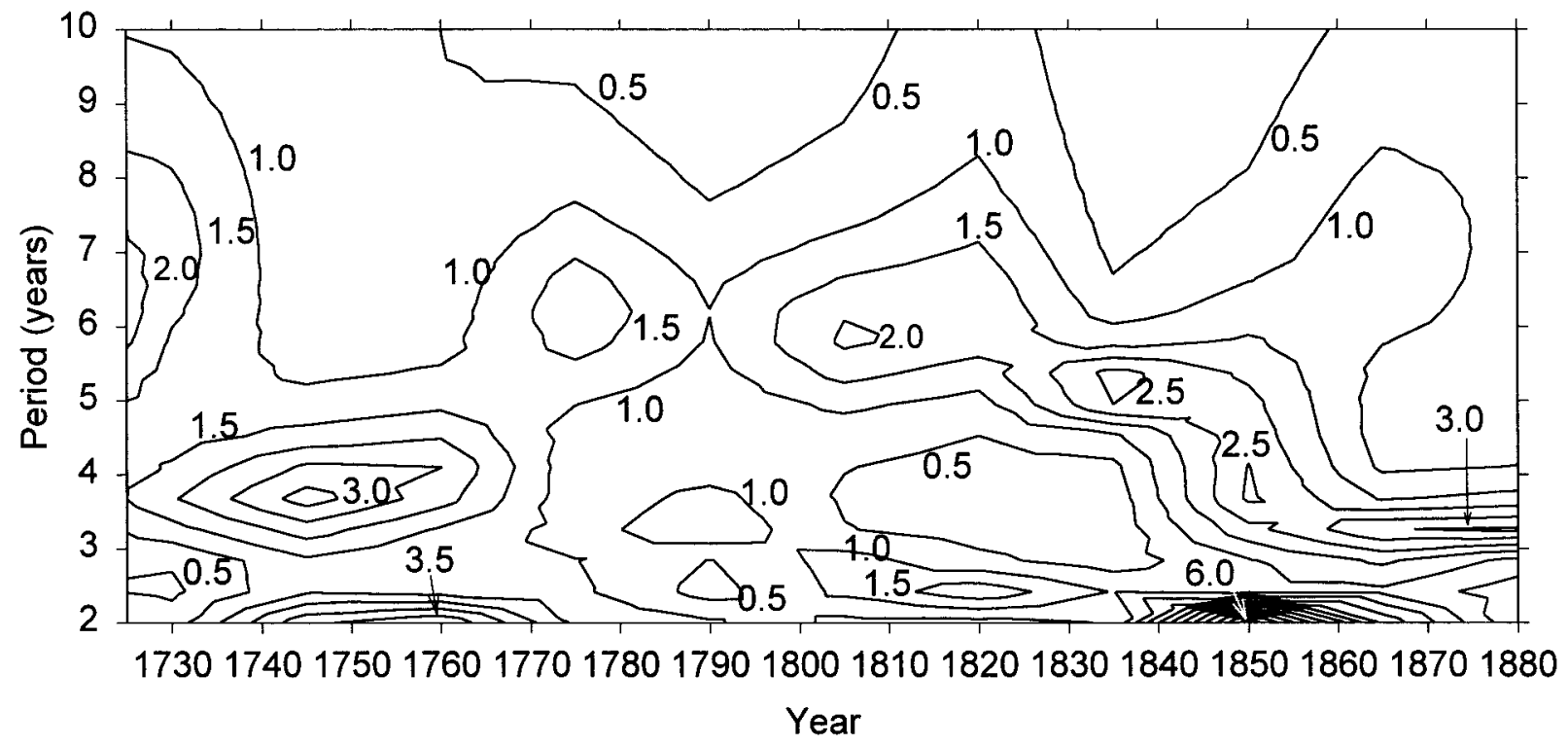

FIG. 10. Evolutionary spectrum of the southwestern United States fire-scar time series, 1700-1900. Maximum entropy spectral analysis (Marple 1987) was used to compute spectra for frequency bands $0.5-3.3$ cycles $\mathrm{yr}^{-1}$ (2-10-yr periods) for 30-yr episodes overlapped by 15 yr. Contours of spectral estimates in standardized units versus time are shown. Biennial oscillations (i.e., circa 2-yr period) and circa 3-4yr oscillations dominated during the midcentury periods, but were weak during the late 1700s to early 1800s when 5-7-yr oscillations become more important. 

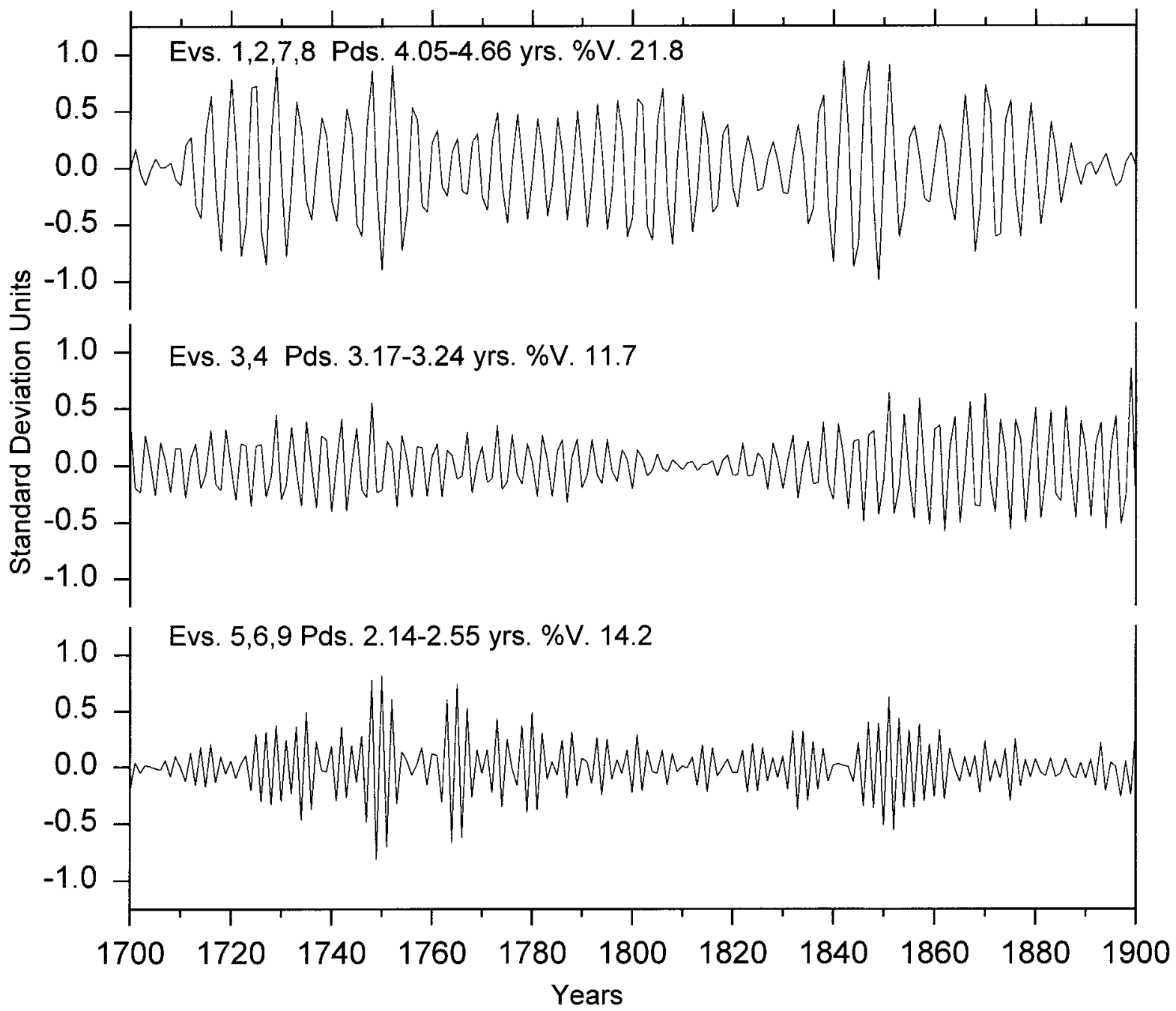

FIG. 11. Dominant waveforms of the southwestern United States fire-scar time series, 1700-1900 derived from singular spectrum analysis (Vautard and Ghil 1989). These are the sums of the reconstructed components from the nine most important eigenvectors; these clustered in the three waveforms with periods varying from about 2.14 to $4.66 \mathrm{yr}$. A reduced amplitude period is common to all three waveforms during the early 1800s. The eigenvector numbers, range of periods, and variance explained in the original time series by the waveforms are shown on the plots.

filled with air, further impeding xylem transport (Tyree and Sperry 1989), and the tree dies from prolonged cavitation, or secondarily from the additional stress of beetle attack.

In the Southwest, these conditions occur whenever the average number of degree days above some threshold temperature is exceeded by a factor of 2 or more in a dry year. Drought years in which this happened include 1904, 1925, 1954, 1956, and 1989. In 1989, regional diebacks occurred across southern and central Arizona in deserts (e.g., Cercidium spp.), chaparral (Quercus emoryi, Arctostaphylos spp.), and woodland conifers (Pinus californiarum var. fallax and P. ponderosa). Dieback in 1989, though conspicuous across the landscape, was greatly exceeded by the catastrophic mortality during the multiyear drought of the 1950s.
The period 1951-56 constitutes one of four major droughts in the United States during the twentieth century (1899-1904 in the southern United States; 1930s or Dust Bowl in the Midwest; and 1980s in the Northwest) (Namias 1955; Thomas 1962; Norwine 1978; Karl and Heim 1990). In the Southwest, it was the worst drought of the century (Fig. 13). The 1950s drought was embedded in a generally dry period between 1942 and 1956, bracketed by the strong ENSO episodes of 194041 and $1956-57$.

Dry winters during the 1950s drought were a consequence of a less sinuous and more northerly polar jet stream, a weakened subtropical jet stream, and a lull in the frequency of El Niño events. Hot, dry summers were common in the late 1940s, and followed dry winters in 1951, 1953, 1954, and 1956. Namias (1955) attributed 


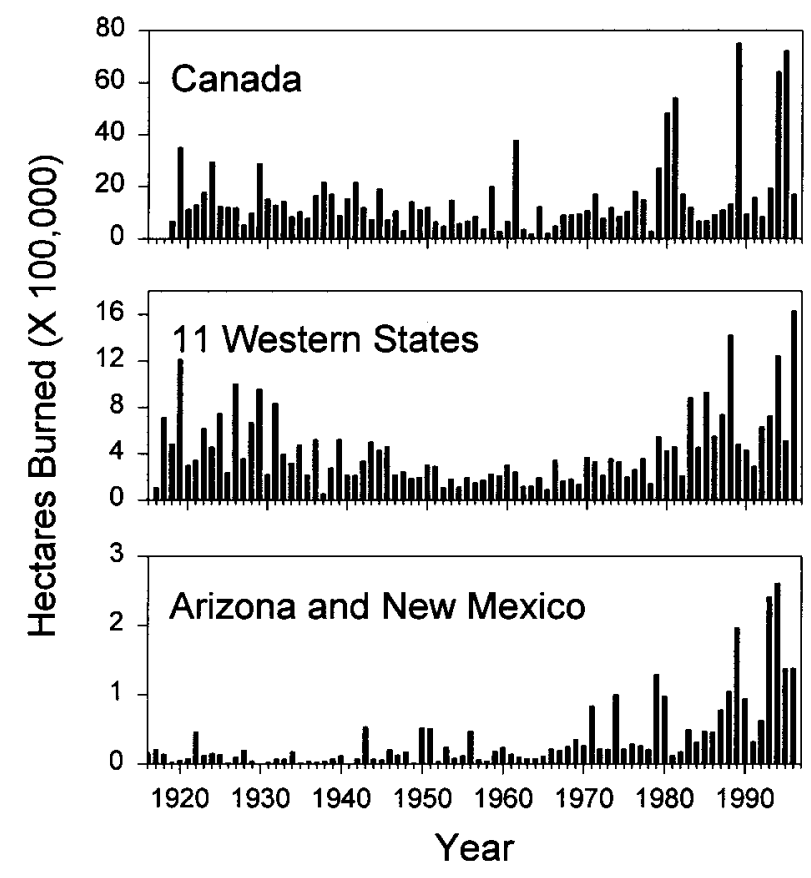

FIG. 12. Annual area burned by wildfires in Canada, the 11 American states west of the Mississippi River, and in Arizona and New Mexico. The data are from all land categories (state, private and federal), 1916-96. Increasing area burned during the late twentieth century may be due to a combination of factors, including accumulated fuels since effective fire suppression began in the early part of the century (but probably not in Canada), and changing climatic patterns. Possible trends in the Canadian data (i.e., increased frequency of large fire years) may be an artifact of more complete data during the late twentieth century.

these dry summers to the anomalous development and positioning of an upper-level anticyclone over the southern United States. Summers in the 1950s also were extremely warm. For example, on the Jornada Experimental Range north of Las Cruces, New Mexico, maximum daily temperature equaled or exceeded $38^{\circ} \mathrm{C}$ on 45 days in 1951, compared to the long-term average of 8 days a year (Herbel et al. 1972).

Dendroclimatologists have recognized the uniqueness of the midcentury drought since Schulman (1956). In the southern United States, the period 1951-56 was the most severe, continuous drought episode since 1700 (Stahle and Cleaveland 1988; Meko et al. 1993). Millennial-long chronologies from the middle Rio Grande Basin in central New Mexico show that the 1950s drought was last exceeded during 1575-95 (D'Arrigo and Jacoby 1991; Grissino-Mayer 1996).

In the Southwest and northern Mexico, massive vegetation dieoffs occurred from the lowland deserts well into the conifer woodlands of the uplands, testimony that the stress tolerance of most species, even droughtadapted ones, was overwhelmed by the drought. Among the species that suffered broadscale mortality were range grasses (Young 1956; Lohmiller 1963; Herbel et al. 1972; Neilson 1986), mesquite (Carter 1964), cacti
(Schulman 1956; Turner 1990), and conifers (Marshall 1957; Betancourt et al. 1993).

The drought altered the composition and age structure of pinyon-juniper woodlands in central and southern New Mexico (Fig. 14). In some areas, these dieoffs contributed to shifts in ecotonal boundaries along moisture (elevational) and edaphic gradients (Marshall 1957). In addition, the 1950 s drought may have played a major role in accelerating shrub invasion of grasslands (Lohmiller 1963; Herbel et al. 1972; Neilson 1986; Grover and Musick 1990).

Although modern human impacts, specifically livestock grazing and fire suppression, may have exacerbated the ecological consequences of the 1950s drought, widespread tree mortality conceivably was matched or exceeded during the sixteenth century drought. Evidence suggesting a major dieoff of conifers during this period derives from a compilation of earliest tree-ring dates from 143 sites in the Southwest (Fig. 15). These data are from tree-ring collections obtained over the past century by several generations of dendrochronologists working at the Laboratory of Tree-Ring Research in Tucson, Arizona. They are composed of the oldest, most climatically sensitive trees that could be found during decades of diligent searching (Swetnam and Brown 1992). Thus, these data are an intensive sampling of the maximum-aged trees in the Southwest. Although the resolution of this age structure data set is low (plus/ minus approximately $10-20 \mathrm{yr}$ ), there is a noticeable decrease in the numbers of surviving trees that recruited into these stands before the late 1500 s. Increased numbers of trees entering the data set during the early $1600 \mathrm{~s}$ may relate to a generally cooler-wetter period that occurred during the 1600 s to 1640s (D'Arrigo and Jacoby 1991; Grissino-Mayer 1996). A previous drop-off in recruitment dates occurred approximately during the late 1200 s, corresponding to a drought made famous by its association (albeit controversial, see Dean 1994) with the Anasazi abandonment of settlements in the Four Corners region of the Southwest.

Clearly, the 1950s drought left a strong imprint on southwestern ecosystems, as well as regional economies (Regensberg 1996). Although the magnitude was similar to the Dust Bowl years, the drought received much less attention because the agricultural impact was buffered by irrigation from groundwater; the overall economic impact was mitigated by the influx of eastern capital for urban growth during the 1950s. Even so, dryland farming and ranching in the Southwest suffered losses in the billions of dollars. The 1950s drought inspired advancements in range hydrology and water conservation measures, and seemingly justified conversion of pinyonjuniper woodland to grassland to improve water yield. An appropriate sensitivity experiment of any model simulating sustainable use of water, range and forest resources would be to pit current resource demands against the backdrop of 1950 s climatic conditions. 


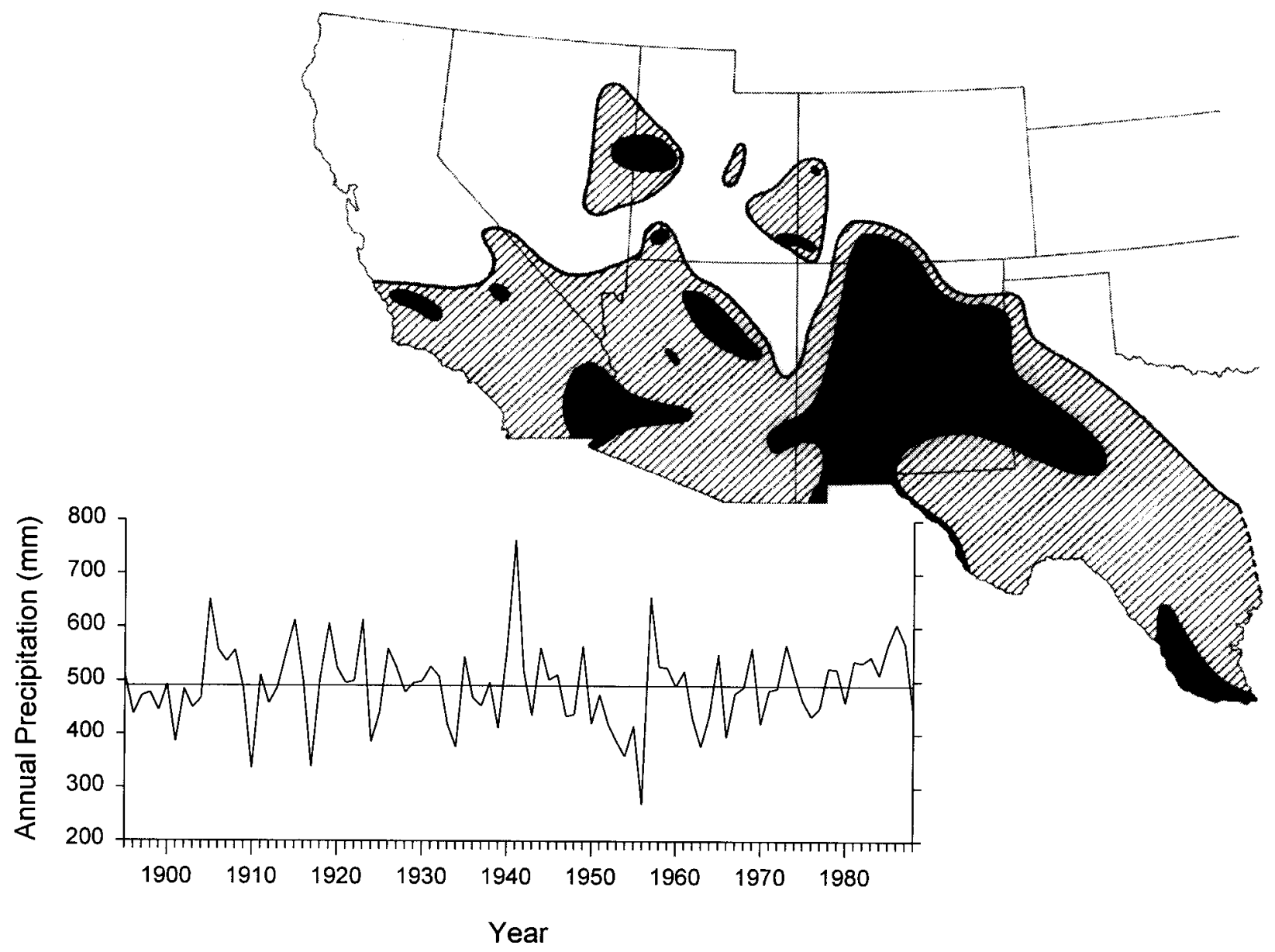

FIG. 13. The map shows areas in the Southwest where precipitation was less than $85 \%$ of the record mean as of 1941 for 8 or more years (hatched areas) and for 10 or more years (black areas) during the period 1942-56 (after Thomas 1962). The time series is the areally weighted annual average precipitation over the Southwest, 1895-1988. These data are the monthly climatic averages compiled by the National Climate Data Center of NOAA for each of the 50 climatic divisions in the Southwest (included in the map area, except the northern halves of the five northern states). These monthly averages were summed for each calendar year by climatic division, and then weighted by the ratio of the divisional area to the total land area in the divisions. The weighted values were then averaged to obtain annual average precipitation over the entire area. Note the depth and duration of the 1950s drought.

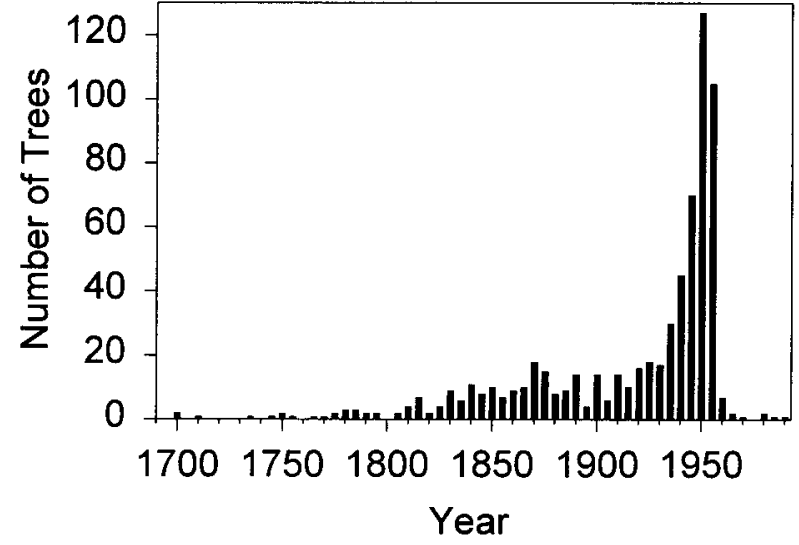

FIG. 14. Death dates of pinyon trees on two plots covering approximately 28 ha in Sevilleta LTER area, Los Pinos Mountain, New Mexico. A total of 1138 trees are included.

\section{Ecological consequences of the post-1976 "wet" period}

The importance of interdecadal variability is underscored by climatic trends since 1976, when the Southern Oscillation locked into the negative, warm (El Niño) phase (Ebbesmeyer et al. 1991). This trend culminated in a recent El Niño (1991-95), which was longer than the prolonged 1911-15 and 1939-42 events. Based on time series modeling, Trenberth and Hoar (1996) suggest that the unusual string of El Niños since 1976 and the protracted 1991-95 event should occur only once every thousand years. In the Southwest, this period produced a string of wet winters and springs, but summer rainfall has been erratic. The erratic summer precipitation offsets the effect of wetter winters and springs in the areally weighted annual averages shown in Fig. 13. However, new thousand-year tree-ring chronologies from New Mexico and Arizona, which are primarily 


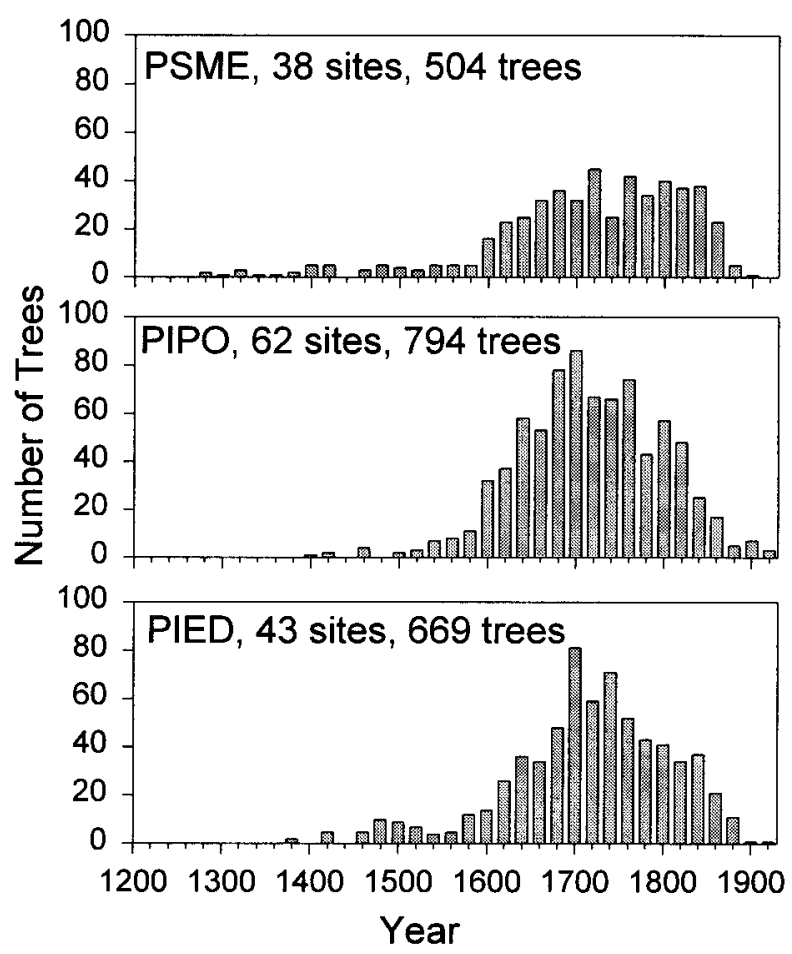

FIG. 15. Innermost ring dates of old-age conifer trees sampled for climate reconstructions in the Southwest (from data archives at the Laboratory of Tree-Ring Research). These dates are grouped in 20$\mathrm{yr}$ increments because the innermost rings from measured specimens did not often include the pith (or approximate establishment date of the tree), but generally were within $10-20 \mathrm{yr}$ of the pith. The species codes shown on the plots are PSME = Douglas-fir; PIPO = ponderosa pine; PIED = pinyon.

sensitive to cool season precipitation, show an unprecedented ramp in tree growth beginning in the mid-1970s (Fig. 16). All of the sites included in Fig. 16 are very isolated with harsh growing conditions (shallow, poor soils, rocky slopes, located on cliffs or in lava flows) where direct human-related impacts, such as logging or livestock grazing, have not occurred. This trend compares with another thousand-year chronology from western Tasmania (Cook et al. 1991), in which increasing tree growth since 1965 has been attributed to anomalous warming. Although $\mathrm{CO}_{2}$ enrichment cannot be ruled out (LaMarche et al. 1984; Graybill and Idso 1993), another reason for the enhanced growth in the Southwest might be mild, wet winters and springs associated with El Niño events. Warmer winter or growing season temperatures might be indicated in these cases because most of these sites are at higher elevations $(>3000 \mathrm{~m})$, where temperature tends to be more important to tree growth, than at lower elevations (Fritts 1991). Other southwestern chronologies from lower elevations do not show the post-1976 surge in ring growth.

The expected outcome of wetter winters-springs for tree demography is accelerated recruitment and improved survivorship into the niches made available by 1950s tree mortality. However, seedling recruitment and age-specific seedling mortality are poorly understood and seldom monitored. More importantly, not enough time has elapsed since 1976 to evaluate long-term survivorship. For example, in our demography plots from the Sevilleta Long-Term Ecological Research area (LTER), we dated the year of establishment for several hundred pinyon seedlings and saplings. A pulse of recruitment since approximately 1976 might be interpreted from these data (Fig. 17). However, since only surviving trees were sampled and mortality rates for seedlings are unknown, these data cannot be evaluated in a long-term perspective because similar survivorship curves are unavailable for comparison with earlier periods in the twentieth century.

The post-1976 climatic change also complicates interpretation of recent vegetation trends. For example, ongoing shrub invasions of southwestern grasslands have been attributed to drought (Herbel et al. 1972; Grover and Musik 1990; Neilson 1986), overgrazingfire suppression (Archer et al. 1995), and even $\mathrm{CO}_{2}$ enrichment driving $\mathrm{C}_{3}$ shrubs into $\mathrm{C}_{4}$ grasslands (Idso 1992; Mayeux et al. 1991; for opposing view see Archer et al. 1995). The debate is confounded by the fact that progressive range deterioration since 1870 has been inferred from historical data (Bahre and Shelton 1993), while long-term monitoring indicates substantial range improvement with better management and wetter conditions following the 1950s drought (Fig. 18; McCormick and Galt 1994). Such ambiguities in disentangling climatic from land-use effects will continue to plague ecosystem research and management in the region.

Lastly, climate appears to be regulating the invasion of exotic plants in the Southwest. Wetter winters since 1976 have encouraged the spread of Eurasian red brome (Bromus rubens), a winter annual, in the upper Sonoran Desert of central and southern Arizona. Consequently, fine fuels have accumulated and large fires have become chronic in desert communities that burned rarely only 20 years ago (Rogers and Vint 1982; McLaughlin and Bowers 1982). Many desert plants, such as saguaros (Carnegiea gigantea), grow slowly and recruit episodically; on decadal timescales, desert fires have irreversible consequences. A shift to drier winters and wetter summers might slow the red brome invasion, while encouraging exotic summer annuals like African buffel grass (Cenchrus ciliare), which becomes flammable in the fall. It is unclear what remedies can be applied, if any. One could propose an aggressive program of fire suppression in the Sonoran Desert. This might be viewed as inconsistent by a ranching community that is increasingly accepting fire as an ecological process capable of holding shrub invasion of grasslands, bordering the Sonoran Desert, at bay.

\section{Conclusions}

An appropriate start for studying climatic effects on ecosystems is to quantify spatial and temporal vari- 


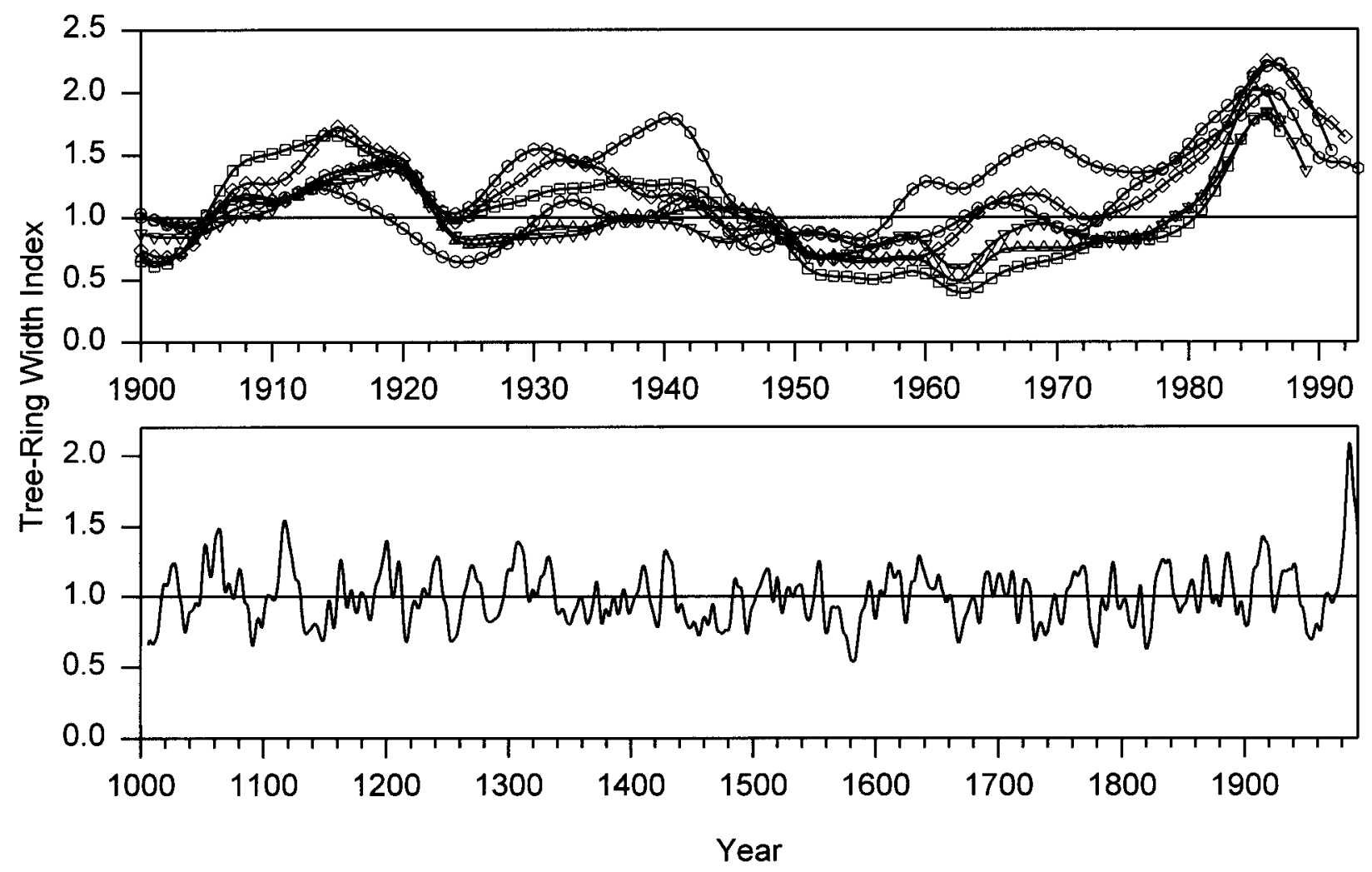

FIG. 16. Millennia-length tree-ring width index chronologies from the Southwest showing an anomalous post-1976 growth surge. The upper plot shows the smoothed (13-weight, low-pass filter) ring-width growth in six sites in New Mexico and Arizona from a variety of species, 1900-93 (squares: Cabresto Canyon, NM, Douglas-fir; circles: Mount Graham, AZ, southwestern white pine; hexagons: Sandia Crest, NM, limber pine; up triangle: Elephant Rock, NM, limber pine; down triangle: Italian Canyon, NM, limber pine; diamonds: El Malpais, Douglas-fir). The lower plot is a simple average of these six chronologies; the post-1976 growth increase is unprecedented during the past $1000 \mathrm{yr}$.

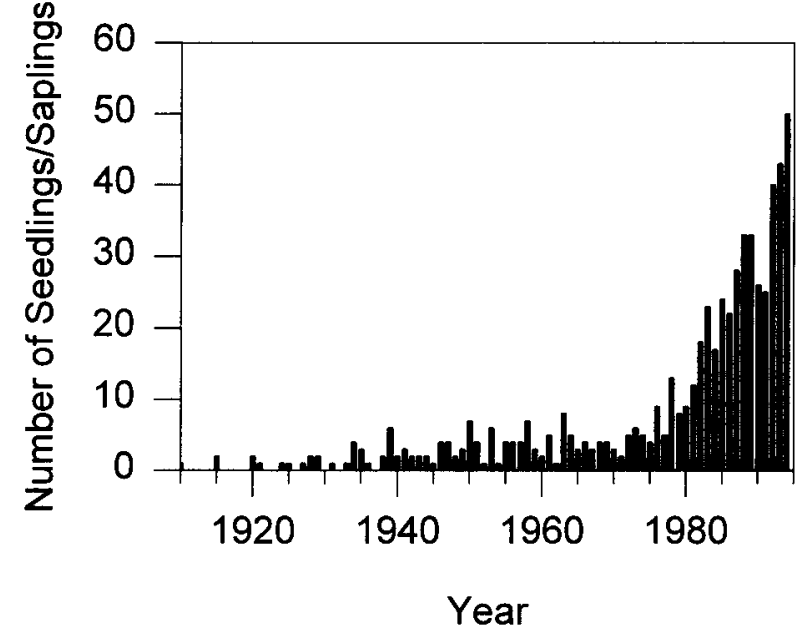

FIG. 17. Innermost ring dates (i.e., approximate germination dates) of pinyon seedlings and saplings sampled in five 0.5-ha plots in the Sevilleta LTER, Los Pinos Mountains, NM. A total of 600 seedlings and saplings were dated, 1900-93. Presently, we cannot ascertain that the rise in number of seedlings after 1976 reflects normal survivorship of younger age classes, exclusion of cattle after this area was fenced, or an unusual pulse in recruitment due to wetter conditions. ability as a function of scale, particularly where scales of variation match (Levin 1992). Understandably, the larger spatial and temporal scales of ecosystem behavior show the greatest variations, and these should be well correlated to climate (McGowan 1990). For example, the strongest correlations between ENSO and area burned emerge from aggregation of fire occurrence data sets from all national forest lands in Arizona and New Mexico, rather than with any particular forest (Swetnam and Betancourt 1990). The more synchronous the fires across a region, the stronger the climate signal. Likewise, climatic trends may not be reflected in the age structure of a single forest or woodland, but should be evident in a summary of tree births and deaths across a region. No matter how problematic, this regional climatic signal should be extracted before variations in ecosystem components can be attributed to other causes, be they intrinsic, in the case of competition and predation, or extrinsic, in the case of human land use.

Climatic variability can amplify or mute anthropogenic effects. Exponential increases in tropical biomass burning in the Amazon Basin coincided with both colonization and drier conditions that were associated with the decadal shift to the negative SO-phase in the 1970s. 

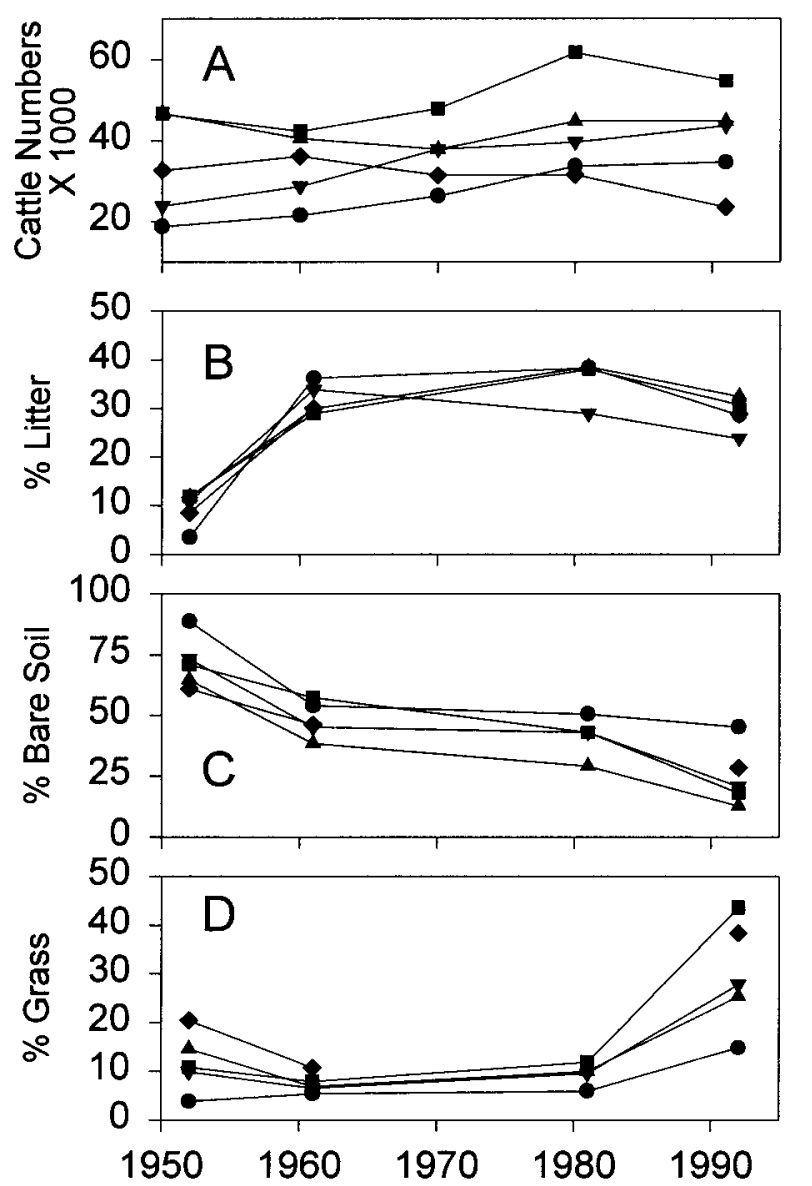

FIG. 18. Summary of (a) cattle numbers, (b) percent litter, (c) percent bare soil, and (d) percent perennial grass at 46 study sites in six southern New Mexico counties, 1952-92 (circles: Doña Ana; squares: Grant; up triangle: Hidalgo; down triangle: Luna; diamond: Otero). These sites are monitored by the Bureau of Land Management to determine range condition trends (McCormick and Galt 1994). The greatest improvement in range condition occurred during the last decade in large part due to recovery of precipitation after range deterioration during the 1950 drought.

Conversely, anthropogenic effects can confound climatic relations. Both numbers of fires and area burned are on the increase in the Southwest and Pacific Northwest, even though interannual and decadal climate variability generally are in opposite phase in these two regions (Dettinger et al. 1996). This may reflect historical fire suppression and the concomitant buildup of woody fuels in both regions. Fuel loads are now far out of equilibrium with natural fire regimes, compounding the effects of the occasional drought (Auclair and Bedford 1994).

The similar trends of increased area burned in the late twentieth century in both the Northwest and Southwest, in the face of opposing climatic trends, could also be due to opposite responses of regional fire regimes to climatic variability. Persistent or frequent droughts in relatively productive northwestern forests may be sufficient to increase fire size and severity. In contrast, large fire years in the less productive forests of the semiarid Southwest may be stimulated by sequences of extreme wet seasons followed by average or drier than average seasons. Fine fuels, such as grasses and tree leaves, accumulate during wet spells, while subsequent dry events favor fire ignition and spread. Even during wet decades in the Southwest, such as the post-1976 period, the arid foresummers are often sufficiently dry for some large fires to occur. When an extremely dry winterspring event eventually follows a wet spell, such as in 1989, exceptionally large areas burn during the following summer (Fig. 12). Compilations of fire-scar records and fire statistics from the Northwest, and detailed comparisons with similar southwestern datasets, are needed to evaluate these changing temporal and spatial patterns over the past several centuries.

Naturalists and ecologists have long noted the severe impacts of mesoscale droughts on plants and animals. Charles Darwin (1855) himself witnessed the aftermath of a great drought-El Gran Seco-in the Argentinean Pampas, where cattle died in the millions after grasslands failed between 1827 and 1830. Ecological study of mesoscale disturbances such as the Gran Seco, however, remains anecdotal. Part of the problem is that historical and regional phenomena are less accessible to experimentation than local processes (i.e., predation and competition) in ecological time (Ricklefs 1987; Brown 1995). With the exception of hurricanes and volcanic eruptions, ecologists have failed to take advantage of mesoscale disturbances as "natural experiments." When it happened, the 1950s drought offered the opportunity to directly study cross-scale and long-term successional processes. Until very recently the drought failed to inspire the appropriate research in the American southwest. Similarly, prolonged drought during the 1980s caused widespread tree mortality across the Pacific Northwest (Wickman 1992), but there has been no regional effort to study this drought or future succession. The Southwest is experiencing unusually wet winters since 1976, yet no one is poised to project the ecological consequences ten to twenty years from now. These missed opportunities suggest that ecologists should pay more attention to mesoscale responses of ecosystems to climatic variability, and specific climatic events, such as drought. Climatologists can play a key role in the multidisciplinary process by focusing on extreme events, and by customizing analytical approaches to match the scales of ecosystem process and variability.

One lesson from our mesoscale aggregations and comparisons of disturbance and climate times series is that ecosystem responses are more variable and complex than is often assumed. These responses are sometimes surprising, and sometimes they offer opportunities for prediction. For example, mesoscale fire activity does not simply correlate with drought; wet conditions and lagging relations between climate and fuels are also involved. These lagging relations, and improved seasonal weather forecasts based on ENSO patterns, suggest that 
quantitative, seasonal fire hazard forecasting tools could be constructed. Outbreaks of one of North America's most widespread and economically important forest insects-the spruce budworm-generally do not occur during droughts, but instead coincide consistently with wet periods. Tree demographic and disturbance responses to climatic variations are confounded by human impacts, but disentangling these influences is possible with comparative analyses of mesoscale datasets.

Our examples of ecological responses to climate in the Southwest underscore the importance of reconstructing, observing, and assessing ecological processes and patterns at the appropriate scales, that is, mesoscales and centuries. Ecological synchroneity at these scales is the hallmark of climatic effects on ecosystems and is a key to separating cultural from natural causes of environmental change. Improved understanding of changing climatic and human controls of keystone ecological processes, such as fire, will require parallel development and comparison of well-dated networks of climatic and ecological time series. In general, ecologists have a great deal to learn from the time series and spatial analytical approaches used by climatologists.

Finally, all ecosystems are historically contingent systems, whose structure and dynamics reflect continuous modification of preexisting systems (Brown 1995). Ecosystem management, then, should be predicated on understanding disturbance processes, ecosystem structures, and history in the context of past, present, and future climate variability.

Acknowledgments. The authors acknowledge financial and logistical support from the USDA Forest Service, Rocky Mountain Research Station (Middle Rio Grande and Borderlands Ecosystem Programs), the Pacific Northwest Research Station, the Nature Conservancy, the Southwest Parks and Monuments Association, the U.S. Geological Survey's Global Change Program (WRD and BRD), and the Sevilleta LTER, which is funded by NSF and managed by the University of New Mexico. For field and laboratory assistance, we especially thank Rena Ann Abolt, Chris Baisan, Shelly Danzer, Paulette Ford, Mark Kaib, Ana MacKay, Henri Grissino-Mayer, Kiyomi Morino, Jim Parks, Jim Speer, and Margot Wilkinson. We also appreciate discussions with Craig Allen, Chris Baisan, Jim Gosz, Jerry Gottfried, Esteban Muldavin, Ann Lynch, Bob Parmenter, Dean Urban, and Boyd Wickman.

\section{REFERENCES}

Andrade, E. R., Jr., and W. D. Sellers, 1988: El Niño and its effect on precipitation in Arizona and western New Mexico. J. Climatol., 8, 403-410.

Archer, S., D. S. Schimel, and E. A. Holland, 1995: Mechanisms of shrubland expansion: Land use, climate or $\mathrm{CO}_{2}$ ? Climate Change, 29, 91-99.

Auclair, A. N. D., 1993: Extreme climatic fluctuations as a cause of forest dieback in the Pacific Rim. Water, Air, Soil Pollut., 66, 207-229.

— , and T. B. Carter, 1993: Forest wildfires as a recent source of CO-2 at northern latitudes. Can. J. For. Res., 23, 1528-1536.

- and J. Bedford, 1994: Conceptual origins of catastrophic forest mortality in the western United States. J. Sustainable For., 2, $249-265$.

Avery, C. C., F. R. Larson, and G. H. Schubert, 1976: Fifty-year records of virgin stand development in southwestern ponderosa pine. USDA Forest Service General Tech. Rep. RM-22, 71 pp.

Bahre, C., and M. L. Shelton, 1993: Historic vegetation change, mesquite increases and climate in southeastern Arizona. J. Biogeog., 20, 489-504.

Balling, R. C., Jr., G. A. Meyer, and S. G. Wells, 1992: Relation of surface climate and area burned in Yellowstone National Park. Agric. For. Meteor., 60, 285-293.

Barbosa, P., and J. C. Schultz, Eds., 1987: Insect Outbreaks. Academic Press, $578 \mathrm{pp}$.

Barden, L. S., 1988: Drought and survival in a self-perpetuating Pinus pungens population: Equilibrium or nonequilibrium? Amer. Midland Nat., 119, 253-257.

Barrows, J., 1978: Lightning fires in southwestern forests. Unpublished report to USDA Forest Service, Northern Forest Fire Laboratory, under Cooperative Agreement 16-568 CA, 154 pp. [Available from Rocky Mountain Research Station Library, 240 West Prospect Rd., Fort Collins, CO 80526.]

Betancourt, J. L., E. A. Pierson, K. Aasen-Rylander, J. A. FairchildParks, and J. S. Dean, 1993: Influence of history and climate on New Mexico pinyon-juniper woodlands. Proc. Managing Pinyon-Juniper Ecosystems for Sustainability and Social Needs, Santa Fe, NM, USDA Forest Service General Tech. Rep. RM236, 42-62.

Blais, J. R., 1962: Collection and analysis of radial-growth data from trees for evidence of past spruce budworm outbreaks. For. Chron., 38, 474-484.

Brenner, J., 1991: Southern Oscillation anomalies and their relation to wildfire activity in Florida. Int. J. Wildland Fire, 1, 73-78.

Brown, J. H., 1995: Macroecology. University of Chicago Press, 269 pp.

, and E. J. Heske, 1990: Temporal changes in a Chihuahuan Desert rodent community. Oikos, 59, 290-302.

Carter, M. G., 1964: Effects of drought on mesquite. J. Range Manage., 17, 275-276.

Cayan, D. R., and R. H. Webb, 1992: El Niño-Southern Oscillation and streamflow in the western United States. El Niño: Historical and Paleoclimatic Aspects of the Southern Oscillation, H. F. Diaz and V. Markgraf, Eds., Cambridge University Press, 29-68.

—, M. D. Dettinger, H. F. Diaz, and N. Graham, 1998: Decadal variability of precipitation over western North America. J. Climate, 11, 3148-3166.

Clark, J. S., 1988: Effect of climate change on fire regimes in northwestern Minnesota. Nature, 334, 233-235.

Cook, E. R., T. Bird, M. Peterson, M. Barbetti, B. Buckley, R. D'Arrigo, R. Francey, and P. Tans, 1991: Climatic change in Tasmania inferred from a 1089-year tree-ring chronology of Huon Pine. Science, 253, 1266-1268.

- D. M. Meko, D. W. Stahle, and M. K. Cleaveland, 1996: Treering reconstructions of past drought across the coterminous United States: Tests of a regression method and calibration/verification results. Tree Rings, Environment, and Humanity: Proceedings of the International Conference, Tucson, Arizona, Radiocarbon, 155-169.

Craighead, F. C., 1925: Bark-beetle epidemics and rainfall deficiency. J. Econ. Entomol., 18, 577-586.

D'Arrigo, R. D., and G. C. Jacoby, 1991: A 1000-year record of winter precipitation from northwestern New Mexico, USA: A reconstruction from tree-rings and its relation to El Niño and the Southern Oscillation. Holocene, 1, 95-101.

_ and $\_$, 1992: Dendroclimatic evidence from northern North 
America. Climate Since A.D. 1500, R. S. Bradley and P. S. Jones, Eds., Routledge, 296-311.

Darwin, C., 1855: Journal of Researches into the Natural History and Geology of the Countries Visited During the Voyage of $\mathrm{H}$. M. S. Beagle Under the Command of Capt. Fitz Roy, R. N. Vol. II. Harper and Brothers, 324 pp.

Dean, J. S., 1994: The Medieval warm period on the southern Colorado plateau. Climate Change, 26, 225-241.

Dettinger, M. D., D. R. Cayan, H. F. Diaz, and D. M. Meko, 1998: North-south precipitation patterns in western North America on interannual-to-decadal timescales. J. Climate, 11, 3095-3111.

Diaz, H., and R. S. Pulwarty, 1994: An analysis of the time scales of variability in centuries-long ENSO-sensitive records in the last 100 years. Climate Change, 26, 317-342.

Douglas, A. V., and P. Engelhart, 1984: Factors leading to the heavy precipitation regimes of $1982-83$ in the United States. Proc. Eighth Annual Climate Diagnostics Workshop, 42-51.

Douglas, M. W., R. A. Maddox, K. Howard, and S. Reyes, 1993: The Mexican monsoon. J. Climate, 6, 1665-1677.

Dunbar, R., G. M. Wellington, M. W. Colgan, and P. W. Glynn, 1994: Eastern Pacific sea surface temperature since 1600 A.D.: The $\mathrm{d}^{18} \mathrm{O}$ record of climate variability in Galapagos corals. Paleoceanography, 9, 291-316.

Ebbesmeyer, C. C., D. R. Cayan, D. R. McLain, F. H. Nichols, D. H. Peterson, and K. T. Redmond, 1991: 1976 step in the Pacific climate: Forty environmental changes between 1968-1975 and 1977-1984. Proc. Seventh Annual Pacific Climate (PACLIM) Workshop, California Department of Water Resources, 115-126.

Elliott, K. J., and W. T. Swank, 1994: Impacts of drought on tree mortality and growth in a mixed hardwood forest. J. Veg. Sci., $\mathbf{5}, 229-236$.

Ferrell, G. T., 1996: The influence of insect pests and pathogens on Sierra Forests. Sierra Nevada Ecosystem Project: Final Report to Congress. Vol. II. Assessments and Scientific Basis for Management Options. University of California, Davis, Centers for Water and Wildland Resources Center Rep. 38, 1177-1192.

Flannigan, M. D., and C. E. van Wagner, 1991: Climate change and wildfire in Canada. Can. J. For. Res., 21, 66-72.

Fritts, H. C., 1976: Tree Rings and Climate. Academic Press, 576 pp.

1991: Reconstructing Large-Scale Climatic Patterns from TreeRing Data: A Diagnostic Analysis. The University of Arizona Press, 286 pp.

— variations in past and present forest environments. Adv. Ecol. Res., 19, 111-189.

Ghil, M., and R. Vautard, 1991: Interdecadal oscillations and the warming trend in global temperature series. Nature, 350, 324 327.

Goldberg, D. E., and R. M. Turner, 1984: Vegetation change and plant demography in permanent plots in the Sonoran Desert. Ecology, 67, 695-712.

Graybill, D. A., and S. B. Idso, 1993: Detecting the aerial fertilization effect of atmospheric $\mathrm{CO}_{2}$ enrichment in tree-ring chronologies. Global Biogeochem. Cycles, 7, 81-95.

Greenidge, K. N. H., 1953: Further studies on birch dieback in Nova Scotia. Can. J. Bot., 31, 548-559.

Grissino-Mayer, H. D., 1996: A 2129-year reconstruction of precipitation for northwestern New Mexico, USA. Tree Rings, Environment, and Humanity: Proceedings of the International Conference: Tucson, Arizona, 17-21 May 1994, Radiocarbon, 191204.

Grover, H. D., and B. Musick, 1990: Shrubland encroachment in southern New Mexico, U.S.A.: An analysis of desertification processes in the American Southwest. Climate Change, 17, 305330.

Hadley, K. S., and T. T. Veblen, 1993: Stand response to western spruce budworm and Douglas-fir bark beetle outbreaks, Colorado Front Range. Can. J. For. Res., 23, 479-491.

Halpert, M. S., and C. F. Ropelewski, 1992: Surface temperature patterns associated with the Southern Oscillation. J. Climate, 5, 577-593.

Harrington, J. A., R. S. Cerveny, and R. C. Balling, 1992: Impact of the Southern Oscillation on the North American southwest monsoon. Phys. Geogr. 13, 318-330.

Herbel, C. H., F. N. Ares, and R. G. Wright, 1972: Drought effects on a semidesert grassland range. Ecology, 53, 1084-1093.

Hinrichsen, D., 1987: The forest decline enigma: What underlies extensive dieback on two continents? BioScience, 37, 542-546.

Huston, M. A., 1994: Biological Diversity: The Coexistence of Species on Changing Landscapes. Cambridge University Press, 681 pp.

Idso, S. B., 1992: Shrubland expansion in the American Southwest. Climate Change, 22, 85-86.

Innes, J. L., 1993: Forest Health: Its Assessment and Status. CAB International, $677 \mathrm{pp}$

Jacoby, G. C., and R. D'Arrigo, 1993: Secular trends in high northern latitude temperature reconstructions from tree rings. Climate Change, 25, 163-177.

Jane, G. T., and T. G. A. Green, 1983: Vegetation mortality in the Kaimai Ranges, North Island, New Zealand. Pac. Sci., 37, 385389.

Johnson, E. A., and D. R. Wowchuck, 1993: Wildfires in the southern Canadian Rocky Mountains and their relationship to mid-tropospheric anomalies. Can. J. For. Res., 23, 1213-1222.

Kahya, E., and J. A. Dracup, 1994: The influences of type 1 El Niño and La Niña events on streamflows in the Pacific southwest of the United States. J. Climate, 7, 965-976.

Karl, T. R., and R. R. Heim Jr., 1990: Are droughts becoming more frequent or severe in the United States? Geophys. Res. Lett., 17, 1921-1924.

Knapp, P. A., 1995: Intermountain west lightning-caused fires: Climatic predictors of area burned. J. Range Manage., 48, 85-91.

LaMarche, V. C., D. A. Graybill, H. C. Fritts, and M. R. Rose, 1984: Increasing atmospheric carbon dioxide: Tree-ring evidence for growth enhancement in natural vegetation. Science, 225, 10191021.

Langston, N., 1995: Forest Dreams, Forest Nightmares: The Paradox of Old Growth in the Inland West. University of Washington Press, $368 \mathrm{pp}$

Larsen, C. P. S., and G. M. MacDonald, 1995: Relations between tree-ring widths, climate, and annual area burned in the boreal forest of Alberta. Can. J. For. Res., 25, 1746-1755.

Larsson, S., 1989: Stressful times for the plant stress-insect performance hypothesis. Oikos, 56, 277-283.

Latif, M., and T. P. Barnett, 1994: Causes of decadal climate variability over the North Pacific and North America. Science, 266, 634-637.

Levin, S. A., 1992: The problem of pattern and scale in ecology: The Robert H. MacArthur Award Lecture. Ecology, 73, 1943-1967.

Lohmiller, R. G., 1963: Drought and its effect on condition and production of a desert grassland range. M.S. thesis, Dept. of Animal and Range Sciences, New Mexico State University, $57 \mathrm{pp}$. [Available from New Mexico State University, Las Cruces, NM 88201.]

Lorio, P. L., Jr., 1986: Growth-differentiation balance: A basis for understanding southern pine beetle-tree interactions. For. Ecol. Manage., 14, 259-273.

Lough, J. M., and H. C. Fritts, 1985: The southern oscillation and tree rings: 1600-1961. J. Climate Appl. Meteor., 24, 952-966. , and - 1987: An assessment of the possible effects of volcanic eruptions on North American climate using tree-ring data, 1602 to 1900 A.D. Climate Change, 10, 219-239.

Luckman, B. H., 1996: Dendrochronology and global change. Tree Rings, Environment and Humanity: Proceedings of the International Conference, Tucson, Arizona, Radiocarbon, 3-24.

Mann, M. E., J. Park, and R. S. Bradley, 1995: Global interdecadal and century-scale climate oscillations during the past five centuries. Nature, 378, 266-270. 
Marple, S. L., 1987: Digital Spectral Analysis: With Applications. Prentice-Hall, 492 pp.

Marshall, J. T., Jr., 1957: Birds of Pine-Oak Woodland in Southern Arizona and Adjacent Mexico. Cooper Ornithological Society, $125 \mathrm{pp}$.

Martin, S. C., 1986: Eighty years of vegetation change on a semidesert range in southern Arizona, U.S.A. and evaluation of causes. Rangelands: A Resource Under Siege, P. J. Ross, P. W. Lynch, and O. B. Williams, Eds., Cambridge University Press, 53.

Martinat, P. J., 1987: The role of climatic variation and weather in forest insect outbreaks. Insect Outbreaks, P. Barbosa and J. C. Schultz, Eds., Academic Press, 241-268.

Mattson, W. J., and R. A. Haack, 1987: The role of drought in outbreaks of plant-eating insects. BioScience, 37, 110-118.

Mayeux, H. S., H. B. Johnson, and H. W. Polley, 1991: Global change and vegetation dynamics. Noxious Range Weeds, L. F. James, J. O. Evans, and R. D. Child, Eds., Westview Press, 62-64.

McCormick, J. C., and H. D. Galt, 1994: Forty years of vegetation trend in southwestern New Mexico. Proc. Symp. on Vegetation Management of the Hot Desert Rangeland Ecosystems, Phoenix, AZ, Society for Range Management, 184-203.

McGowan, J. A., 1990: Climate and change in oceanic systems: The value of time series data. Trends Ecol. Evol., 5, 293-299.

McLaughlin, S. P., and J. E. Bowers, 1982: Effects of wildfire on a Sonoran Desert plant community. Ecology, 63, 246-248.

Meko, D. M., E. R. Cook, D. W. Stahle, C. W. Stockton, and M. K. Hughes, 1993: Spatial patterns of tree-growth anomalies in the United States and southeastern Canada. J. Climate, 6, 17731786.

, C. W. Stockton, and W. R. Boggess, 1995: The tree-ring record of severe sustained drought. Water Resour. Bull., 31, 789-801.

Michaelsen, J., and L. G. Thompson, 1992: A comparison of proxy records of El Niño-Southern Osillation. El Niño: Historical and Paleoclimatic Aspects of the Southern Oscillation, H. F. Diaz, and V. Markgraf, Eds., Cambridge University Press, 323-348.

Miller, A. J., D. R. Cayan, T. P. Barnett, N. E. Graham, and J. Oberhuber, 1994: Interdecadal variability of the Pacific Ocean: Model response to observed heat flux and wind stress anomalies. Climate Dyn., 9, 287-302.

Mooney, C. Z., and R. D. Duvall, 1993: Bootstrapping: A nonparametric approach to statistical inference. Quantitative Applications in the Social Sciences, Vol. 95, Sage Publications, 96 pp.

Mopper, S., and T. G. Whitham, 1992: The plant stress paradox: Effects on pinyon sawfly sex ratios and fecundity. Ecology, 73, $515-525$.

Namias, J., 1955: Some meteorological aspects of drought, with special reference to the summers of 1952-54 over the United States. Mon. Wea. Rev., 83, 199-205.

- X. Yuan, and D. R. Cayan, 1988: Persistence of North Pacific sea surface temperature and atmospheric flow patterns. J. Climate, 1, 682-703.

Neilson, R. P., 1986: High-resolution climatic analysis and southwest biogeography. Science, 232, 27-34.

Norwine, J., 1978: Twentieth-century semi-arid climates and climatic fluctuations in Texas and northeastern Mexico. J. Arid Environ., 1, 313-325.

Overpeck, J. T., D. Rind, and R. Goldberg, 1990: Climate induced changes in forest disturbance and vegetation. Nature, 343, 5153.

Pake, C. E., and D. L. Venable, 1995: Is coexistence of Sonoran desert annuals mediated by temporal variability in reproductive success? Ecology, 76, 246-261.

Pearson, G. A., 1950: Management of Ponderosa Pine in the Southwest. Agric. Monogr., No. 6, USDA Forest Service, 218 pp.

Pickett, S. T. A., and P. White, Eds., 1985: The Ecology of Natural Disturbance and Patch Dynamics. Academic Press, 472 pp.

Plummer, F. G., 1912: Forest fires: Their causes, extent and effects, with a summary of recorded destruction and loss. USDA For. Serv. Bull., 117, 38 pp.
Price, C., and D. Rind, 1994: The impact of a $2 \times \mathrm{CO}_{2}$ climate on lightning-caused fires. J. Climate, 7, 1484-1494.

Price, P. W., 1991: The plant vigor hypothesis and herbivore attack. Oikos, 62, 244-251.

Pyne, S. J., 1982: Fire in America: A Cultural History of Wildland and Rural Fire. Princeton University Press, $654 \mathrm{pp}$.

Quinn, W. H., and V. T. Neal, 1992: The historical record of El Niño events. Climate Since 1500, R. S. Bradley, and P. D. Jones, Eds., Routledge, Chapman and Hall, 623-648.

Rasmusson, E. M., X. Wang, and C. F. Ropelewski, 1990: The biennial component of ENSO variability. J. Mar. Syst., 1, 71-96.

Redmond, D. R., 1995: Rootlets, mycorrhiza, and soil temperatures in relation to birch dieback. Can. J. Bot., 33, 595-672.

Regensberg, A., 1996: General dynamics of drought, ranching, and politics in New Mexico, 1953-1961. New Mexico Hist. Rev., 71 (1), 25-49.

Ricklefs, R. E., 1987: Community diversity: Relative roles of local and regional processes. Science, 235, 167-171.

Rogers, G. F., and M. K. Vint, 1987: Winter precipitation and fire in the Sonoran Desert. J. Arid Environ., 13, 47-52.

Rogers, P., 1996: Disturbance ecology and forest management: A review of the literature. Intermountain Forest and Range Experiment Station General Tech. Rep. INT-GTR-336, USDA Forest Service, 16 pp.

Romme, W. H., 1982: Fire and landscape diversity in subalpine forests of Yellowstone National Park. Ecol. Monogr., 52, 199-221.

Rothermel, R. C., 1983: How to predict the spread and intensity of forest and range fires. Intermountain Forest and Range Experiment Station General Tech. Rep. INT-143, USDA Forest Service, $161 \mathrm{pp}$.

Sackett, S., S. Haase, and M. G. Harington, 1994: Restoration of Southwestern ponderosa pine ecosystems with fire. Proc. Sustainable Ecological Systems: Implementing an Ecological Approach to Land Management, Flagstaff, AZ, USDA Forest Service General Tech. Rep. RM-247, 115-121.

Sanders, C. J., R. W. Stark, E. J. Mullins, and J. Murphy, Eds., 1985: Recent Advances in Spruce Budworms Research. Proc. CANUSA Spruce Budworms Research Symp., Bangor, ME, Canadian Forestry Service.

Savage, M., 1994: Anthropogenic and natural disturbance and patterns of mortality in a mixed conifer forest in California. Can. J. For. Res., 24, 1149-1159.

— P. M. Brown, and J. Feddema, 1996: The role of climate in a pine forest regeneration pulse in the southwestern United States. Ecoscience, 3, 310-318.

Schowalter, T. D., W. W. Hargrove, and D. A. Crossley Jr., 1986: Herbivory in forested ecosystems. Annu. Rev. Entomol., 31, 177196.

Schulman, E., 1956: Dendroclimatic Changes in Semi-Arid America. The University of Arizona Press, $142 \mathrm{pp}$.

Shiyatov, S. G., V. S. Mazepa, E. A. Vaganov, and F. H. Schweingruber, 1996: Summer temperature variations reconstructed by tree-ring data at the polar timberline in Siberia. Tree Rings, Environment and Humanity: Proceedings of the International Conference: Tucson, Arizona, 17-21 May 1994, Radiocarbon, $61-70$.

Simard, A. J., D. A. Haines, and W. A. Main, 1985: Relations between El Niño-Southern Oscillation anomalies and wildland fire activity in the United States. Agric. For. Meteor., 36, 93-104.

Slowey, N. C., and T. J. Crowley, 1994: Interdecadal variability of Northern Hemisphere circulation recorded by Gulf of Mexico corals. Geophys. Res. Lett., 22, 2345-2348.

Sousa, W. P., 1984: The role of natural disturbance in natural communities: Annu. Rev. Ecol. Systematics, 15, 353-391.

Sprugel, D. G., 1991: Disturbance, equilibrium and environmental variability: What is "natural vegetation" in a changing environment? Biol. Conser., 58, 1-18.

Stahle, D. W., and M. K. Cleaveland, 1988: Texas drought history reconstructed and analyzed from 1698 to 1980. J. Climate, 1, $59-74$ 
- and - 1993: Southern Oscillation extremes reconstructed from tree rings of the Sierra Madre Occidental and southern Great Plains. J. Climate, 6, 129-140.

Stocker, T. F., and L. A. Mysak, 1992: Climatic fluctuations on the century time scale: A review of high resolution proxy data and possible mechanisms. Climate Change, 20, 227-250.

Stocks, B. J., 1987: Fire potential in the spruce budworm-damaged forests of Ontario. For. Chron., 63, 8-14.

Swetnam, T. W., 1993: Fire history and climate change in giant sequoia groves. Science, 262, 885-889.

_, and J. L. Betancourt, 1990: Fire-Southern Oscillation relations in the southwestern United States. Science, 24, 1017-1020.

_ , and P. M. Brown, 1992: Oldest known conifers in the southwestern United States: Temporal and spatial patterns of maximum age. Proc. Workshop on Old-Growth Forests in the Rocky Mountains and Southwest: The Status of Our Knowledge, Portal, AZ, USDA Forest Service General Tech. Rep. RM-GTR213, 2438 .

- and A. Lynch, 1993: Multi-century, regional-scale patterns of western spruce budworn history. Ecol. Monogr., 63, 399-424. , and C. H. Baisan, 1996: Historical fire regime patterns in the Southwestern United States since AD 1700. Proc. Second La Mesa Fire Symp., Los Alamos, NM, USDA Forest Service General Tech. Rep. RM-GTR286, 11-32.

- B. E. Wickman, G. H. Paul, and C. H. Baisan, 1995: Historical patterns of western spruce budworm and Douglas-fir tussock moth outbreaks in the Northern Blue Mountains, Oregon, since A.D. 1700. USDA Forest Service, Pacific Northwest Forest Experiment Station Res. Paper PNW-RP-484, 27 pp.

Thomas, H. E., 1962: The meteorological phenomenon of drought in the Southwest: Drought in the Southwest, 1942-1956. U.S. Geological Survey Prof. Paper 342A, 43 pp.

Trenberth, K. E., and J. W. Hurrell, 1994: Decadal atmosphere-ocean variations in the Pacific. Climate Dyn., 9, 303-319.

_, and T. J. Hoar, 1996: The 1990-1995 El Niño-Southern Oscillation event: Longest on record. Geophys. Res. Lett., 23, 5760.

Turner, M. G., W. H. Romme, R. H. Gardner, R. V. O’Neill, and T.
K. Kratz, 1993: A revised concept of landscape equilibrium: Disturbance and stability on scaled landscapes. Landscape Ecol., 8, 213-227.

Turner, R. M., 1990: Long-term vegetation change at a fully protected Sonoran desert site. Ecology, 71, 464-477.

Tyree, M. T., and J. S. Sperry, 1989: Vulnerability of xylem to cavitation and embolism. Ann. Plant Phys. Mol. Bio., 40, 19-38.

van Wagner, C. E., 1988: The historical pattern of annual burned area in Canada. For. Chron., 64, 182-185; Erratum, 64, 319.

Vautard, R., and M. Ghil, 1989: Singular spectrum analysis in nonlinear dynamics, with applications to paleoclimatic time series. Physica, 35D, 395-424.

Villalba, R., and T. T. Veblen, 1997: Regional patterns of tree population age structures in northern Patagonia: Climatic and disturbance influences. J. Ecol., 85, 113-124.

Waring, R. H., 1987: Characteristics of trees predisposed to die. BioScience, 37, 569-574.

Webb, R. H., and J. L. Betancourt, 1992: Climatic effects on flood frequency of the Santa Cruz River, Pima County, Arizona. U.S. Geological Survey Water-Supply Paper 2379, 40 pp.

Weber, U., and F. H. Schweingruber, 1995: A dendroecological reconstruction of western spruce budworm outbreaks (Choristoneura occidentalis) in the Front Range, Colorado, from 1720 to 1986. Tree, 9, 204-213.

White, A. S., 1985: Presettlement regeneration patterns in a southwestern ponderosa pine stand. Ecology, 66, 589-594.

White, P. S., and S. T. A. Pickett, 1985: Natural disturbance and patch dynamics: An introduction. The Ecology of Natural Disturbance and Patch Dynamics, S. T. A. Pickett and P. S. White, Eds., Academic Press, 3-13.

White, T. C. R., 1976: Weather, food, and plagues of locusts. Oecologia, 22, 119-134.

Wickman, B. E., 1992: Forest health in the Blue Mountains: The influence of insects and diseases. USDA Forest Service General Tech. Rep. PNW-GTR-310, 11 pp.

$\mathrm{Xu}$, J., 1993: The joint modes of the coupled atmosphere-ocean system observed from 1967 to 1987. J. Climate, 6, 816-838.

Young, V. A., 1956: The effects of the 1949-1954 drought on the ranges of Texas. J. Range Manage., 9, 139-142. 